\title{
How network-based incubation helps start-up performance: a systematic review against the background of management theories
}

\author{
Chris P. Eveleens ${ }^{1} \cdot$ Frank J. van Rijnsoever $^{1}$ • \\ Eva M. M. I. Niesten ${ }^{2}$
}

Published online: 4 October 2016

(C) The Author(s) 2016. This article is published with open access at Springerlink.com

\begin{abstract}
The literature on how network-based incubation influences the performance of technology-based start-ups has recently grown considerably and provided valuable insights. However, at the same time this literature has become quite fragmented, inconsistently conceptualised, and theoretically underdeveloped. Therefore, this article uses three management theories to structure the literature, improve the theoretical underpinning and develop an agenda for further research. The management theories are the resourcebased view, knowledge-based view, organisational learning, and social capital theory. We find that the network-based incubation literature has convincingly shown that networkbased incubation provides start-ups with resources, capabilities, knowledge, learning and social capital. However, the influence of these intermediary benefits on start-up performance is ambiguous. There is a considerable opportunity to advance the network-based incubation literature with contemporary insights from management theories. We propose an agenda for further research on network-based incubation that leads to a fine-grained model of the mechanisms and impact of network-based incubation that goes beyond taken for granted assumptions about the positive impact of network-based incubation.
\end{abstract}

Keywords Incubation · Entrepreneurs $\cdot$ Network $\cdot$ Performance $\cdot$ Resources $\cdot$ Social capital

JEL Classification L26 - O32 - O31 · M13

Chris P. Eveleens

c.p.eveleens@uu.nl

1 Innovation Studies Group, Copernicus Institute for Sustainable Development, Utrecht University, Heidelberglaan 2, 3584 CS Utrecht, The Netherlands

2 Alliance Manchester Business School, The University of Manchester, Booth Street West, Manchester M15 6PB, UK 


\section{Introduction}

Business incubation aims to help starting ventures by providing access to services and resources (NBIA 2009). Incubation of technology-based start-ups has received considerable attention from policymakers and business people for its promise to contribute to technology transfer and entrepreneurship (Aernoudt 2004; Clarysse et al. 2005; Phan et al. 2005). Over the last five decades, the number of incubators has increased to more than 7000 worldwide (NBIA 2014). During this period, incubators changed their way to support start-ups (Bruneel et al. 2012). The first generation of incubators focused primarily on providing infrastructure; the second-generation incubation supplemented their way of operating by providing one-on-one business advice. Recently, incubators have augmented their approach by focusing on facilitating networks. Through these networks, start-ups access intangible resources such as knowledge and legitimacy (Bruneel et al. 2012). This shift in focus echoes the observation that intangible resources particularly help start-ups (Brüderl and Preisendörfer 1998; Chen 2009).

Researchers have tried to keep up with the changing nature of incubation (Grimaldi and Grandi 2005; Hackett and Dilts 2004). Consequently, in 2000, the network-based view of incubation was formulated and gained considerable interest (Hansen et al. 2000). Notably, the question of whether and how network-based incubation influences start-ups' performance remained important (Ratinho et al. 2013). After all, as the earlier generations of incubation were found to improve start-up performance only marginally (Schwartz 2013), the network-based generation was expected to be superior in achieving that aim. The increased attention on network-based incubation resulted in a rich and broad variety of approaches, conceptualisations and insights (Theodorakopoulos et al. 2014). However, as the field of literature grew, two major shortcomings emerged.

Firstly, research on the influence of network-based incubation on start-up performance has led to contradictory results. Some studies demonstrate that network-based incubation does not improve start-ups' performance (Chan and Lau 2005; Oakey 2007; Soetanto and Jack 2013). Other studies argue that network-based incubation does lead to improved startup performance (Hansen et al. 2000; Hughes et al. 2007; Patton 2014). These contradictory results might be the consequence of the heterogeneity of network-based incubation in terms of incubation practices (Aernoudt 2004), contextual differences (Soetanto and van Geenhuizen 2010) or a focus on distinctive performance measures. Because the causes of these contradictory results have been studied in isolation, it has been impossible to compare them. Furthermore, research has focused on different types of intermediary benefits for the incubated start-ups and the theoretical mechanisms associated with them. Studies have looked at the influence of network-based incubation on benefits such as learning (Hughes et al. 2007), resources (Soetanto and Jack 2013) and social capital (Tötterman and Sten 2005). Until now, these benefits and network-based mechanisms have mainly been studied separately. This makes it difficult to compare their relative importance in explaining start-up performance.

Secondly, the incubation literature is rather descriptive and focused on best practices (Duff 1994; Fernández 2012; Milius 2008). The network-based incubation literature is no different. Authors use theoretical perspectives from management, but according to several authors, these are applied with limited theoretical depth (Ahmad and Ingle 2013; Amezcua et al. 2013; Hackett and Dilts 2004). For example, Ahmad and Ingle (2013, p. 136) state: "There is a lack of a theoretically grounded basis for explaining this variation in incubator 
performance." This limited theoretical depth is unfortunate. Theories can help to identify the mechanisms that explain start-up performance.

To overcome these shortcomings and advance the understanding of the contemporary generation of business incubation, we will perform the first systematic literature review on network-based incubation. The overall aim of this study is to analyse the literature on the influence of network-based incubation on start-up performance through the lenses of three management theories. We use the theories that are most often applied in this context. These are the resource-based view (RBV), the knowledge-based view (KBV) and organisational learning (OL), and social capital theory (SCT). Our contribution is threefold. Firstly, we assess the empirical evidence about the influence of network-based incubation on start-up performance. We focus on the network-based mechanisms that impact start-up performance. Secondly, we assess the mechanisms in the network-based incubation literature against the background of the management theories. In doing so we can identify causes of contradictory findings and gaps in the network-based incubation literature. Finally, we suggest avenues for future research that improve the understanding of how network-based incubation helps start-ups.

We structure the rest of this article as follows. In Sect. 2, we describe our methods. In Sect. 3, we first present the findings with regard to start-up performance as the dependent variable and network-based incubation as the independent variable. We continue Sect. 3 by discussing the mechanisms that explain the relationship between network-based incubation and start-up performance. Section 4 unfolds a synthesis of the findings and an agenda for further research, and Sect. 5 concludes the article.

\section{Methods}

This systematic literature review consisted of a step-by-step process for content analysis (Mayring 2000a; Shapiro and Markoff 1998). The steps are material collection, descriptive analysis of the material, selection of the main conceptual categories and evaluation of the material pertaining to these categories (Mayring 2000b).

We identified a complete set of scientific articles on the influence of network-based incubation on start-up performance. We define network-based incubation as business support that is offered by a dedicated organisation to a group of technology-based startups through networks (Ahmad and Ingle 2011; Bøllingtoft and Ulhøi 2005; Hansen et al. 2000). We further required the articles to focus on the level of the start-up, instead of only on the level of the incubator or region. The material collection commenced with a search query in Thomson Reuters Web of Science database, last run in April 2015. The search string consisted of two parts acting as two criteria with which the articles needed to comply. Firstly, the title or abstract of the articles needed to contain "incubat*" ${ }^{1}$ to ensure that the article focuses on our topic of interest. Secondly, we are interested in networks and interaction. Therefore, the title or abstract of the articles needed to also contain "network*", "interact*", "relat*", "collaborat*", "cooperat*", "tie*", or "link*". We restricted the search to English articles in the 'business economics' research

\footnotetext{
1 The asterisk is a "wildcard character" to include alternative word endings.
} 
area, covering business, economics and management journals. ${ }^{2}$ This led to an initial set of 207 articles.

These articles were then qualitatively assessed on their relevance to the aim of our study. Because our initial search was quite broad, we had to exclude a total of 157 articles. Of these discarded articles, we excluded most articles because they did not fit our definition of network-based incubation (82 articles). ${ }^{3}$ Furthermore, 67 articles did not sufficiently focus on network-based incubation, start-up performance or the relationship between the two. ${ }^{4}$ Finally, we excluded eight articles because they did not provide an empirical contribution. The final set consisted of 50 articles, which are listed in the "Appendix".

For all the articles, we have listed the topic, theoretical perspective, year, research approach, performance measures and network characteristics. The articles were published between 1996 and 2014, with only three articles published before 2000 and the majority (36) published since 2007. The articles were published in 26 journals, of which eight articles are published in Technovation, six in the Journal of Technology Transfer and five in $R \& D$ Management.

Investigating the research design, the material includes 21 qualitative studies. These usually provide rich case studies of specific incubation programmes (e.g. Sá and Lee 2012; Schwartz and Hornych 2008), discussing how start-ups interact (Bøllingtoft and Ulhøi 2005; Cooper et al. 2012); the role of the incubation manager (Patton and Marlow 2011; Rice 2002); and how this might lead to benefits for the start-up (Patton et al. 2009; Tötterman and Sten 2005; Vick et al. 2013). Twenty studies are quantitative. They describe the services and resources of the incubator for start-ups (Hansen et al. 2000; Scillitoe and Chakrabarti 2010); the difference between incubated start-ups and non-incubated start-ups (Colombo and Delmastro 2002); and the influence of interaction in the incubator on performance (Hughes et al. 2007a; b; Soetanto and van Geenhuizen 2009; Soetanto and Jack 2013; Sullivan and Marvel 2011). The remaining nine studies use mixed methods - for example, to study incubator case studies from different angles (e.g. Mian 1996; Rothaermel and Thursby 2005b; Salvador 2011) or to complement largely quantitative studies with illustrative interviews (Li and Chen 2009; Sherman and Chappell 1998).

Considering the theoretical perspectives of the articles, all but two of the articles are based on three theoretical perspectives. The first is the resource-based view (RBV). The 33 articles that adopt the RBV perspective focus on how a start-up can access and acquire different types of resources in network-based incubation (McAdam and McAdam 2008; Soetanto and van Geenhuizen 2009). The knowledge-based view (KBV) and organisational learning (OL) combined are the second theoretical perspective. We merge these views as they are closely related. KBV sees knowledge as the most important resource for organisations to be successful and OL is about how organisations acquire, distribute, interpret and structure this knowledge (Huber 1991). The 23 articles that use a KBV or OL perspective focus on the acquisition of knowledge and on the learning processes of the start-up

\footnotetext{
${ }^{2}$ Business economics covers journals focusing on business (including marketing and advertising, forecasting, planning, administration, organisational studies, strategy, retailing, consumer research, management, business history and business ethics); economics (theoretical and applied journals of the production, distribution, and consumption of goods and services, including generalist as well as specialist resources, such as political economy, agricultural economics, macroeconomics, microeconomics, econometrics, trade, and planning); and management (including management science, organisation studies, strategic planning and decision-making methods, leadership studies, and total quality management) (Thomson Reuters Social Science Citation Index 2012).

3 Several articles refer to a city, region or website as an incubator of ideas (Giuri et al. 2010; Heebels and Boschma 2011).

${ }^{4}$ For example, incubation was mentioned as a recommendation for entrepreneurship or university policy, although it was not the focus of the study (Sharif 2012).
} 
in network-based incubation (e.g. Hughes et al. 2007; Patton and Marlow 2011). The third theoretical perspective is that of social capital theory (SCT). The 12 articles on SCT study the value of goodwill among actors in network-based incubation and the benefits that result from this goodwill (e.g. Bøllingtoft and Ulhøi 2005; Hughes et al. 2007). Several articles use more than one theoretical perspective.

The selection of conceptual categories enables a systematic analysis of the articles. These categories are based on the dependent (start-up performance) and independent variables (network-based incubation) and on the main constructs of the theoretical perspectives. We then structured the literature according to these categories using an interpretivistic approach (Mayring 2000a). We read the articles and compared the concepts in these articles to the definitions from the management theories, thereby combining insights from qualitative and quantitative articles. When the categorisation was not straightforward, we consulted a colleague to verify our interpretation. All categories and subcategories are provided in Table 1 and are discussed in the findings section.

\section{Findings}

This findings section consists of five subsections. In the first two, we discuss the conceptualisation and analysis of start-up performance and network in the network-based incubation literature. In these first two subsections, we limit ourselves to discussing the methodological and conceptual considerations of the reviewed articles. The third, fourth and fifth subsections discuss the network-based incubation literature through the RBV, $\mathrm{KBV}$ and OL, and SCT lenses, respectively. In these subsections, we discuss the theoretical mechanisms, the network-based incubation practices and the impact of network-based incubation on start-up performance. Figure 1 below shows which articles have informed us on which relationships between the main concepts.

All five subsections are structured in such a way such that a formal comparison is made between the conceptual categories of the theoretical perspectives and the network-based incubation literature. Each subsection closes with a synthesis of the results, limitations of incubation research and suggestions for further incubation research.

\subsection{Performance}

\subsubsection{Concepts and definitions}

Firm performance is one of the most widely used dependent variables in business and management literature. Dimensions of firm performance are efficiency, growth, profit, size, liquidity, success versus failure, market share and leverage (Murphy et al. 1996; Richard et al. 2009). For measuring start-up performance, the literature uses a host of performance measures. Typical performance measures are employment growth, market share, gross profit, cost control, business volume, survival, successful exit, goal attainment, evaluation of success by the founder, and completion of idea or planning phase (Baron et al. 2016; Brush and Vanderwerf 1992; Chandler and Hanks 1993; Dutta and Folta 2016; Lumpkin and Dess 1996; Stam and Elfring 2008; Wiklund and Shepherd 2003; Witt 2007). Although there are many definitions and approaches to measuring the performance of businesses, doing so is not straightforward (Chandler and Hanks 1993; Richard et al. 2009). Performance measures can be either objective when using, for example, financial statements, or 
Table 1 Conceptual categories of analysis

\begin{tabular}{|c|c|c|}
\hline & Category & Concepts \\
\hline \multirow[t]{4}{*}{$\begin{array}{l}\text { Start-up } \\
\text { performance }\end{array}$} & $\begin{array}{l}\text { General objective } \\
\text { measures }\end{array}$ & $\begin{array}{l}\text { Success, survival, firm size, firm growth in terms of sales, profit } \\
\text { and employment, and total of funds obtained }\end{array}$ \\
\hline & $\begin{array}{l}\text { Incubation-specific } \\
\text { objective measures }\end{array}$ & $\begin{array}{l}\text { Firm graduation from the incubator and number of lifted } \\
\text { obstacles }\end{array}$ \\
\hline & $\begin{array}{l}\text { General subjective } \\
\text { measures }\end{array}$ & $\begin{array}{l}\text { Anticipated survival, success, market or business performance, } \\
\text { achievement of entrepreneurial goals, estimation of growth, } \\
\text { competitive performance, estimated sales, performance } \\
\text { compared to competitors, estimation of profit, and satisfaction } \\
\text { with the return on assets }\end{array}$ \\
\hline & $\begin{array}{l}\text { Incubation-specific } \\
\text { subjective measures }\end{array}$ & $\begin{array}{l}\text { Advancement in the incubation process from initiation to } \\
\text { commercialisation }\end{array}$ \\
\hline \multirow[t]{3}{*}{ Network } & Actors & $\begin{array}{l}\text { Incubation manager, mentors, researchers, universities, informal } \\
\text { investors, venture capitalists, consultants, and service } \\
\text { providers }\end{array}$ \\
\hline & Relationships & $\begin{array}{l}\text { The content, the formality, the strength of the relationships, the } \\
\text { form of relationship communication, and whether it is an } \\
\text { incubator-internal or incubator-external relationship }\end{array}$ \\
\hline & $\begin{array}{l}\text { Approach to measuring } \\
\text { the network }\end{array}$ & Metaphorical and analytical \\
\hline \multirow[t]{2}{*}{ RBV } & Resources & $\begin{array}{l}\text { Funding, office space, a general network, specific contacts, } \\
\text { technical knowledge, managerial knowledge, advice, a sense } \\
\text { of belonging, and credibility }\end{array}$ \\
\hline & Capabilities & $\begin{array}{l}\text { Innovative capabilities, managerial capabilities, marketing } \\
\text { capabilities, network capabilities }\end{array}$ \\
\hline \multirow[t]{2}{*}{$\mathrm{KBV} / \mathrm{OL}$} & Knowledge & Technical, market, business, tacit and codified knowledge \\
\hline & Learning & Explorative and exploitative learning \\
\hline \multirow[t]{3}{*}{ SCT } & Social capital & Structural dimension of social capital \\
\hline & & Relational dimension of social capital \\
\hline & & Homophily dimension of social capital \\
\hline
\end{tabular}

subjective when relying on people's judgement (Chandler and Hanks 1993; Stam and Elfring 2008). Neither objective nor subjective performance measures are superior in accurately measuring performance (Chandler and Hanks 1993; Richard et al. 2009). Objective measures are limited to those aspects of the business that can be measured and emphasise historical performance, while subjective measures have the risk of psychological biases (Richard et al. 2009).

For measuring start-up performance, additional challenges emerge. Firstly, start-ups are not required to report their performance to public shareholders, making it difficult to obtain data. Secondly, the changes in a start-up's development are relatively large and erratic (Garnsey et al. 2006). This makes the moment at which the performance is measured important. Thirdly, industry characteristics and entrepreneurs' ambitions vary considerably, making it difficult to compare absolute measures (Chandler and Hanks 1993). Finally, start-up performance measures hardly correlate and some even correlate negatively, such as profitability and growth (Cooper 1993; Murphy et al. 1996; Witt 2007). As such, the choice of a performance measure alone can greatly influence the outcome of a scientific study, and can lead to seemingly contradictory results. Many scholars therefore use a combination of measures (Wiklund and Shepherd 2003). 


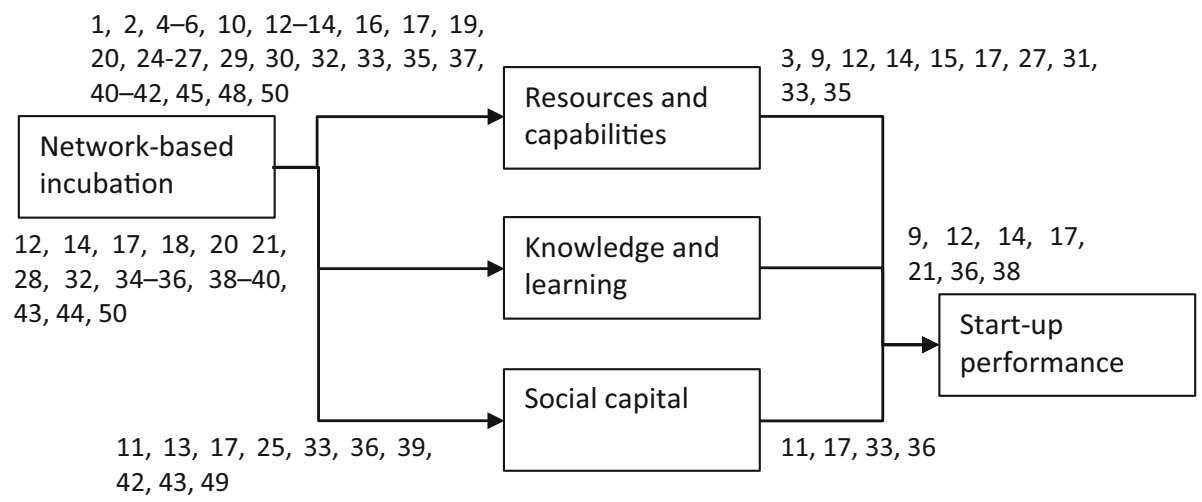

Fig. 1 Conceptual model. The numbers refer to the articles discussing this relationship (see "Appendix")

\subsubsection{Reviewing the network-based incubation literature}

The measures of start-up performance used in the incubation literature are in line with how start-up performance is commonly assessed in the business and management literature (see "Appendix" for all performance measures). In the network-based incubation literature, 12 articles adopt one or a combination of objective measures. These are success/survival (three articles), and firm size and firm growth in terms of sales, investments, revenue, profit and employment (eight articles). Two articles use the total capital raised as a performance measure (Rothaermel and Thursby 2005b; Sherman and Chappell 1998). Three articles use incubation-specific objective measures, being firms graduating from the incubator (McAdam and McAdam 2008; Rothaermel and Thursby 2005a) and the number of obstacles lifted by the incubator (Van Geenhuizen and Soetanto 2009). The subjective measures in the literature are based on assessment by the entrepreneur or by the incubator manager. The articles that measure performance subjectively (16 articles) use anticipated survival/success (five articles), market or business performance (five articles), achievement of entrepreneurial goals (two articles), estimation of growth (two articles), competitive performance (two articles), estimated sales (two articles), performance compared to competitors (one article), estimation of profit (one article), and satisfaction with the return on assets (one article). Additionally, an incubation-specific subjective measure is the advancement in the incubation/start-up process from initiation to commercialisation (two articles). In 21 articles, firm performance is not the focus of the study. In these studies, performance is not directly measured, but theoretically assumed to follow from improved capabilities, resources, social capital or learning.

\subsubsection{Reflection and further research}

According to the assessed management literature, the choice of performance measure has a considerable impact on the outcome of a study (Cooper 1993; Murphy et al. 1996; Witt 2007). Furthermore, there is no single performance measure without its limitations. There are many articles that do not measure performance, which prevents us from using these articles to assess the overall impact of network-based incubation. Considering the challenges, the network-based incubation literature pays little attention to the choice of 
performance measure. In line with the management theories, our review shows that the network-based incubation literature uses a broad variety of measures (e.g. Bøllingtoft 2012 Sullivan and Marvel 2011; Sung 2007). Furthermore, because performance measures are only used once or twice throughout the literature, it is difficult to compare outcomes between articles. Because network-based incubation can influence performance measures in distinct ways, using alternative performance measures between studies might explain contradictory findings. We suggest that further research uses a more consistent and broad combination of performance measures (i.e. growth, profitability, value, short-term, longterm). This enables us to identify the influence of network-based incubation on different dimensions and measures of start-up performance.

\subsection{Network-based incubation}

\subsubsection{Concepts and definitions}

Network-based incubation helps start-ups to develop their network. The basic elements of a network are nodes and the ties that connect these nodes (Ozman 2009; Wasserman and Faust 1994; Witt 2007). Nodes are typically defined at different organisational levels, like firms (Powell et al. 1996), divisions (Tsai 2002), projects (Van Rijnsoever et al. 2015), or individuals (Cantner and Graf 2006). Nodes can also be categorised in terms of actor types, including large firms, small firms, universities and government. Ties usually represent relational characteristics, including friendship, cooperation, power, and exchange of advice, assets or information (Hoang and Antoncic 2003; Slotte-Kock and Coviello 2010; Witt 2007). Research typically considers one specific type of relationship, but it is also possible to consider multiple relationships (Phelps et al. 2012).

While the concept of a network implies a certain degree of explicitness (a set of nodes and ties), many studies approach the concept more loosely to represent some kind of interdependence or embeddedness, without making the nodes and ties explicit. Bergenholz and Waldstrøm (2011) introduce the distinction between approaching the network metaphorically or analytically. Studies taking a metaphorical approach acknowledge that there is some type of interaction between social entities, but do not specify this. Analytical studies acknowledge specific social structures between nodes and tend to measure these formally. In analytical studies, it is possible to use social network analysis, making these comparable and specific in terms of network structure (Bergenholtz and Waldstrøm 2011).

The network of a firm influences its performance (Aldrich and Zimmer 1986; Brüderl and Preisendörfer 1998; Gulati et al. 2000). A central position and strong relationships typically enhance performance because of information, power, learning and resource advantages (Powell et al. 1996). However, a central position and strong relationships can also limit the performance, because they are costly to maintain and can blind the business to new developments (Burt 2004; Uzzi 1997). These benefits and limitations from networks for start-up performance are discussed in detail in the subsections covering the theoretical perspectives.

\subsubsection{Reviewing the network-based incubation literature}

A network-based incubation programme aims to help the start-up to form and develop its network. As a result, the start-up network typically consists of relationships with several actors (Hansen et al. 2000; Rothschild and Darr 2005; Schwartz and Hornych 2010; 
Tötterman and Sten 2005). We are interested in the part of the network that is affected by network-based incubation.

The network-based incubation literature largely agrees about the type of actors (i.e. nodes) of the start-up network. These are universities (Mian 1996; Rothaermel and Thursby 2005a), incubator managers (Rice 2002; Tsai et al. 2009), consultants (Tötterman and Sten 2005), financiers (Sá and Lee 2012) and other start-ups (Schwartz and Hornych 2008).

The network-based incubation literature describes different types of tie, mirroring the diversity from the management literature. The type of tie varies mainly along five dimensions: the content (i.e. what is exchanged; 21 articles); the formality (13 articles discuss this); the strength of the relationships (five articles); the form of the relationship's communication (two articles) and whether it is an incubator-internal or incubator-external relationship (two articles). ${ }^{5}$ Furthermore, 21 articles do not specify the type of relationship.

The reviewed literature uses the concept of network more in a metaphorical ( 34 articles) than analytical manner (16). The studies taking a metaphorical approach acknowledge the existence of many relationships between actors, but do not formally measure these. Although considerable value is assigned to the network, it remains unclear where precisely this value comes from. The studies that do take an analytical approach usually study only a specific relationship with a certain actor, such as the university (Hansen et al. 2000; Rothaermel and Thursby 2005b; Rothschild and Darr 2005), other start-ups (Cooper et al. 2012) and suppliers or clients (Ebbers 2013). Although these studies clarify the relationship of focus, they are generally unable to compare the relative importance of different types of relationship.

\subsubsection{Reflection and further research}

The network-based incubation literature has approached the network from a variety of angles, but mainly metaphorically. The exploratory character of the research field legitimises this approach. However, at this point, the field can benefit from more analytical network research that goes beyond focusing on a specific relationship. A comprehensive analytical approach provides a better understanding of the influence of network-based incubation on start-up performance. More specifically, measuring networks more formally enables the use of network analysis measures such as centrality and clustering. These can show the influence of network-based incubation on the centrality and clustering of the start-up network, and as a result the start-up performance. Determining the strength and direction of these relationships will enrich the research field. A reason for the lack of more analytical network studies is that for a long time it has been challenging to collect formal network data. However, the increasing availability of social network data (e.g. Twitter, e-mail and LinkedIn) can help to resolve this problem.

\subsection{Resource-based view}

\subsubsection{Theoretical assumptions}

The resource-based view sees firms as bundles of resources and capabilities by which products and services are developed to provide the firms with returns (Penrose 1959; Wernerfelt 1984). Resources are "stocks of available factors that are owned or controlled

\footnotetext{
5 Articles can distinguish several dimensions.
} 
by the firm", such as financial, human or physical assets (Amit and Schoemaker 1993, p. 35). Resources are unequally distributed over firms and imperfectly mobile, which enables some organisations to achieve a competitive advantage over other firms (Barney 1991).

To outperform competitors, a firm needs resources that are valuable in the sense that they must exploit opportunities or neutralise threats in a firm's environment, and be rare among current and potential competitors. Furthermore, to achieve a lasting performance, the resources need to be imperfectly imitable and non-substitutable by other resources (Barney 1991; Dierickx and Cool 1989). The valuable, rare, inimitable and non-substitutable (VRIN) resources are a subset of all the resources of a business. Examples of typical VRIN resources are technological knowledge, trust between employer and employees, and a credible brand name. The VRIN criteria are crucial when assessing the overall value of a set of resources. They distinguish between those resources that provide a sustainable competitive advantage for organisations and those resources that are common and easily acquired.

While controlling a bundle of VRIN resources is necessary to maintain a high performance, it is not sufficient (Barney 2001; Crook et al. 2008; Fahy 2000; Newbert 2007). Resources need to be identified, acquired, developed and used in such a way that returns are optimised. Therefore, firms need capabilities, which are defined as the "capacity to deploy resources, usually in combination, using organizational processes, to effect a desired end" (Amit and Schoemaker 1993, p. 35). Acknowledging the importance of capabilities complements the perception of which VRIN resources are important with insight into how they lead to performance. There are many capabilities. In a review of 19 articles, as many as 28 different capabilities were identified, including technical capabilities, managerial capabilities and innovative capabilities (Newbert 2007).

While resources are typically developed within the firm, scholars have argued that important resources can also be located outside the firm (Dyer and Singh 1998; Lavie 2006). Firms use their network to tap into resources from other organisations. However, specific capabilities are needed to benefit from these shared resources. Important capabilities are absorptive capability (Wang and Ahmed 2007), network capability (Walter et al. 2006), and the relational capability of managing shared resources (Blyler and Coff 2003; Dyer and Singh 1998; Lavie 2006; Walter et al. 2006). Absorptive capability is "the ability of a firm to recognize the value of new, external information, assimilate it, and apply it to commercial ends" (Cohen and Levinthal 1990, p. 128). Network capability is the "ability to initiate, maintain, and utilize relationships with various external partners" (Walter et al. 2006, p. 546). The relational capability of managing shared resources is the capacity to form and maintain valuable interactive relationships with partners (Lavie 2006). Without such capabilities, the latent benefits of a network cannot be capitalised upon.

\subsubsection{Reviewing the network-based incubation literature}

The majority (33) of the reviewed articles use RBV. ${ }^{6}$ Literature from the RBV perspective views network-based incubation as an instrument that helps start-up develop their network. This network, consisting of various actors possessing various resources and capabilities,

\footnotetext{
${ }^{6}$ An article uses the RBV perspective when it explicitly states so, or when major constructs from the theory (e.g. resources and capabilities) are focused on in a way congruent with the RBV perspective.
} 
can then provide the necessary resources and capabilities to start-ups. These resources and capabilities should then lead to improved start-up performance.

Extant literature has identified a long list of resources, of which the most prevalent are funding, office space, a general network and specific contacts, technical knowledge, managerial knowledge, advice, a sense of belonging and credibility (Hansen et al. 2000; Soetanto and Jack 2013; Sullivan and Marvel 2011; Tötterman and Sten 2005). Credibility often remains undefined, which means that its value is left implicit. Following Van Rijnsoever et al. (2014), we define credibility as the trustworthiness, expertise and reliability of the start-up. It is provided to start-ups by network-based incubation through association with established actors from the network-based incubation programme, such as universities, investors and business experts (Bøllingtoft 2012; McAdam and McAdam 2008). The extent to which these are VRIN resources is hardly assessed, however. Furthermore, literature shows that network-based incubation can influence the capabilities of the start-up. Network-based incubation increases the innovative capabilities (one article), managerial capabilities (two articles), marketing capabilities (three articles), network capabilities (one article) and technological capabilities (five articles) of the start-up (Chen and Wang 2008; Fang et al. 2010; Hughes et al. 2007; Li and Chen 2009).

The RBV articles approach the network more metaphorically (24 articles) than analytically (nine articles). Mainly through qualitative research, the network-based incubation literature describes the practices through which these resources and capabilities are transferred to the start-up (Hansen et al. 2000; Rothschild and Darr 2005; Sá and Lee 2012; Scillitoe and Chakrabarti 2010; Soetanto and Jack 2013). Firstly, the incubation organisation provides all incubated start-ups with a general network and credibility (Bøllingtoft and Ulhøi 2005; Sá and Lee 2012; Schwartz and Hornych 2008). Secondly, mentors and coaches provide start-ups with specific knowledge, capabilities, advice, encouragement to interact and specific referrals (Patton et al. 2009; Rice 2002). Thirdly, other start-ups provide the start-up with basic advice (Bøllingtoft and Ulhøi 2005; Tötterman and Sten 2005). Fourthly, external actors in the network of the incubation organisation provide startups with funding, technical knowledge and market intelligence (Hansen et al. 2000; Rothaermel and Thursby 2005a; Rothschild and Darr 2005).

From the perspective of the start-up, access to these resources would seem to be beneficial to their performance. In the articles using RBV, start-up performance is measured objectively (ten articles, e.g. sales and employment growth rate) as well as subjectively (eight articles, e.g. advancement in the commercialisation process and satisfaction with market share). Other RBV-based articles do not focus on performance, but assume it theoretically ${ }^{7}$ (15 articles). The seemingly conflicting positive and negative impact of resources and capabilities on performance requires further assessment. Technology commercialisation capabilities are associated with higher start-up performance satisfaction by the entrepreneur (Chen 2009). The resources that stem from a relationship with a university improve start-up survival, but are negatively associated with revenue, funds obtained and incubator graduation (Rothaermel and Thursby 2005a, b). Resources from networking with internal actors improve competitive performance, but not growth in terms of jobs (Hughes et al. 2007; Soetanto and Jack 2013). Depending on the resources and performance measure, we find both positive and negative associations.

\footnotetext{
7 Some articles study how incubation leads to some resources and assume that these resources lead to performance. Whether they actually lead to performance is not empirically investigated.
} 


\subsubsection{Reflection and further research}

The findings show that the idea that resources and capabilities from network-based incubation simply lead to start-up performance in general is flawed. The network-based incubation literature has started only by identifying which resources and capabilities lead to change in which dimensions of start-up performance. This implies that in further research it is important to acknowledge heterogeneity and adopt a sufficiently broad set of performance measures.

Furthermore, it is important to focus on those resources that are most likely to affect start-up performance. This points to taking into account the VRIN criteria, which are currently almost completely lacking in the literature. That is to say, in network-based incubation, many of the resources that are provided are not rare-for example, office space, funding and general advice are common resources found within and outside network-based incubation.

Capabilities are generally more VRIN oriented. The network-based incubation literature has started to identify important capabilities. Furthermore, start-ups need network capabilities and absorptive capabilities to access and acquire network-based incubation VRIN resources. Complementing the question of which resources are relevant, these capabilities can also explain how the resources are acquired and turned into performance.

\subsection{Knowledge-based view and organisational learning}

\subsubsection{Theoretical assumptions}

According to $\mathrm{KBV}$, knowledge is the most crucial resource to determine firm performance. Because all other resources are more easily transferred, they cannot give a durable advantage over competitors (Grant 1996a). Organisational learning can be seen as the process of acquiring, distributing, interpreting and structuring this crucial knowledge (Dodgson 1993; Huber 1991). Networks can play an important role in acquiring and interpreting knowledge.

Various types of knowledge are distinguished. They differ in how they influence the performance of the firm (Dodgson 1993; Grant 1996b; Johnson et al. 2002). Codified knowledge (Cowan, David and Foray 2000; Kogut and Zander 1992) is structured into a set of rules and relationships that can easily be stored in written documents and communicated. Knowledge that is not codified is called tacit knowledge (Cowan et al. 2000). It resides in people, routines and institutions and it is therefore more difficult to communicate (Kogut and Zander 1992; Levitt and March 1988). Another dimension of the type of knowledge is the content of the knowledge. For start-ups, three types of knowledge are found to be particularly important in relation to firm performance: technological, market and practical business knowledge (Shane 2000; Vohora et al. 2004; Wiklund and Shepherd 2003; Wright et al. 2008). Technological knowledge refers to that which is known about a specific technology and how a technical product or service functions (Burgers et al. 2008; Mowery et al. 1996; Rosenberg and Nelson 1994). Market knowledge refers to that which is known about the market and includes knowledge about customer needs, distribution channels, business models, rules, regulations and competitors (Burgers et al. 2008; Cohen and Levinthal 1990). Business knowledge refers to how to set up and run a business and includes administrative knowledge, knowledge about raising funds, drawing up and signing contracts, and hiring staff (Vohora et al. 2004). 
The field of organisational learning distinguishes different types of learning. Learning influences the performance of an organisation in different ways (Crossan et al. 1999; Easterby-Smith et al. 2000). We focus here on the distinction between individual and social learning (Wang and Chugh 2014) and on explorative versus exploitative learning (Fiol and Lyles 1985; March 1991). These types of learning provide relevant and complementary insights into start-ups' learning because they balance short-term and long-term benefits (especially exploitation and exploration) and recognise that entrepreneurs learn in relation to their start-up team or environment (social learning).

Individual learning takes place within the individual (Wang and Chugh 2014), while social learning posits that "learning occurs through close contact with other people and observation and imitation of role model behaviours (Bandura 1977)" (Wang and Chugh 2014, p. 39). While individual learning is usually more time consuming, it can result in more original ideas (Wang and Chugh 2014). Social learning is usually more efficient, but learning is limited to those insights that have been previously acquired by others. The two influence one another and are complementary, as individual learning can be based on insights acquired through social learning (Bergh et al. 2009; Crossan et al. 1999). For startups, there is a tension between the efficiency of social learning and the need for individually learned, original entrepreneurial ideas (Lumpkin and Dess 1996; Wang and Chugh 2014).

Considering explorative and exploitative learning, explorative learning entails the "experimentation with new alternatives" (March 1991, p. 85). Because start-ups are involved with identifying new opportunities and introducing new products or services, exploration is important for them (Wiklund and Shepherd 2003). As such, exploration is important for innovation. However, because the returns of exploration are uncertain, distant and often negative, exploration is risky and costly. On the other hand, exploitative learning is "the refinement and extension of existing competences, technologies, and paradigms" (March 1991, p. 85). For start-ups, exploitative learning is associated with the exploitation of identified opportunities by gradually improving the start-up activities (Wiklund and Shepherd 2003). Because the returns of exploitation are positive, proximate and predictable, firms usually have little trouble pursuing this activity. However, too much focus on exploitation can lead to a lock-in, making the firms susceptible to external shocks (March 1991). The challenge of staying competitive for firms in general and for start-ups specifically is to balance exploration and exploitation (He and Wong 2004; March 1991).

\subsubsection{Reviewing the network-based incubation literature}

The KBV and OL perspectives are quite widely applied in the network-based incubation literature: 22 articles use the KBV and nine articles the OL perspective (of which six combine the two $){ }^{8}$ From these perspectives, network-based incubation offers an environment that is conducive to learning. Start-ups learn, and thereby acquire knowledge, by interacting with various actors. From these actors, start-ups can acquire different types of knowledge. This knowledge can then contribute to start-up performance.

The articles with a KBV perspective identify the types of knowledge that are acquired by the start-up through the network. Most studies approach the network metaphorically (14 articles) and the remainder analytically (eight articles). In the metaphorical approach, the network is seen as an opportunity or latent source of knowledge, without explicitly

\footnotetext{
${ }^{8}$ An article uses the KBV or OL perspective when it explicitly states so, or when major constructs from the theory (e.g. knowledge or learning) are focused on in a way congruent with the KBV and/or OL perspective.
} 
distinguishing the relationships. The articles that take a more analytical approach focus on measuring the characteristics and impact of a specific relationship, such as that between the start-up and the university (Rothaermel and Thursby 2005a), between the start-up and the incubator manager (Fang et al. 2010; Rice 2002), or between different start-ups (Cooper et al. 2012).

Through different network-based incubation practices, start-ups access several types of knowledge. Five of the articles distinguish between tacit and codified knowledge. Being the more strategic type of knowledge, tacit knowledge can be exchanged particularly well in network-based incubation because of the physical and cognitive proximity of the actors (Cooper et al. 2012). Furthermore, several articles find that technical (five articles), market (five articles) and business (eight articles) knowledge are acquired by the start-up through relationships with different actors in network-based incubation programmes (Warren, Patton and Bream 2009). Start-ups acquire technical knowledge from interacting with the incubator manager, mentors and external contacts offered by the incubator manager (Fang et al. 2010; Patton and Marlow 2011; Scillitoe and Chakrabarti 2010). Start-ups acquire market knowledge from interacting with the incubator manager in counselling sessions and from meetings with mentors (Patton and Marlow 2011; Scillitoe and Chakrabarti 2010). Business knowledge is acquired from interaction with the incubator manager (Fang et al. 2010; Patton and Marlow 2011). The role of fellow start-ups in providing business knowledge is debated, as some articles find that they can help overcome basic business problems (Cooper et al. 2012), while other articles find no valuable knowledge coming from fellow start-ups (Hughes et al. 2007; Patton and Marlow 2011).

Moving beyond the type of knowledge, network-based incubation literature has started to identify those factors that influence knowledge acquisition. In general, relying on a broad network improves knowledge acquisition of start-ups, explained by an improved absorptive capacity (Rothaermel and Thursby 2005b; Sullivan and Marvel 2011). Furthermore, in the relationship with the incubator manager, the intensity of his/her involvement in the start-up is a second factor, where active coaching is superior to passive in the transfer of knowledge (Clarysse and Bruneel 2007; Rice 2002). Moreover, in the relationship with other start-ups, more trust, better aligned commercial objectives and more activities organised by the incubator seem to improve the transfer of knowledge (McAdam and Marlow 2007; Oakey 2007; Patton 2014; Vick et al. 2013). These contextual factors capture the considerable variation of network-based incubation.

From the KBV perspective, six articles study start-up performance objectively (e.g. firm size and growth in terms of employees) and five subjectively (phase in commercialisation process), while ten do not focus on the start-up performance. Knowledge from relationships in the network-based incubation influences the start-up performance in two seemingly contrasting ways. On the one hand, start-ups perform better in terms of innovation when they acquire technological knowledge from others (Rothaermel and Thursby 2005b; Sullivan and Marvel 2011). Because the start-ups that rely heavily on their network have a higher absorptive capacity, they are better equipped to judge and use the technical knowledge. This chimes with the advantage of social learning (two articles). Start-ups use the experience of others to obtain knowledge that is relevant for their business (Fang et al. 2010; Patton and Marlow 2011). On the other hand, start-ups seem to perform worse in terms of market performance when relying heavily on the network (Hughes et al. 2007). That is to say, successful entrepreneurs have to be independent, and by relying too heavily on their network for knowledge, their performance decreases as they start copying others. This contradicts the idea of social learning in which network-based incubation facilitates and points to the value of individual learning (two articles). This confirms our suspicion 
that, depending on the performance measure, network-based incubation can lead to seemingly contradictory consequences.

Only two articles explicitly discuss explorative and exploitative learning. Networkbased incubation facilitates both types of learning in different ways (Patton and Marlow 2011). Explorative learning results from interaction with actors external to the incubation programme (Patton and Marlow 2011). Because this new knowledge comes from people with very different backgrounds compared to that of the entrepreneurs, it sometimes disrupts their assumptions. Exploitative learning takes place mainly as a result of the interaction between start-ups and the incubator manager, and provides knowledge and solutions that are usually in line with the start-ups' business activities and assumptions. Start-ups are inclined to rely strongly on exploitative learning because it is safe and efficient (Hughes et al. 2007; Sá and Lee 2012). However, focusing too much on exploitation leads to a performance decrease (Hughes et al. 2007). This is because the knowledge that is acquired through exploitation is limited and incremental (Hughes et al. 2007). Therefore, while incubation can facilitate in both exploration and exploitation, it is important for the start-up that it does not fall into the trap of copying others too much. This requires network-based incubation programmes not only to offer opportunities for both exploration and exploitation, but also to make sure that the start-ups are sufficiently compelled to pursue both.

\subsubsection{Reflection and further research}

Similar to insights derived from the RBV perspective, the relationship between networkbased incubation and start-up performance is more ambiguous than is portrayed in extant literature. The network-based incubation literature demonstrates that acquiring knowledge from one's network can simultaneously improve innovative performance and worsen market performance. The choice of performance measure is therefore of major importance in this field.

Furthermore, the context of network-based incubation is quite varied and this context influences knowledge acquisition by the start-up. The assumption that knowledge from network-based incubation will automatically lead to improved start-up performance is too simplistic. Potential contextual factors to take into account are the type of industry, characteristics of the incubation programme, institutional environment and characteristics of the relationships.

Finally, few articles focus on learning processes in network-based incubation programmes. There are different benefits and limitations associated with different types of learning. How network-based incubation can stimulate and balance different types of learning and how this then relates to different dimensions of start-up performance is a promising avenue for further research.

\subsection{Social capital theory}

\subsubsection{Theoretical assumptions}

Social capital can be seen as "the good-will that is engendered by the fabric of social relations and that can be mobilized to facilitate action" (Adler and Kwon 2002, p. 17). It has been extensively applied in the broader fields of sociology (Coleman 1988; Portes 1998) and management (Adler and Kwon 2002; Burt 2000), including entrepreneurship (Stam et al. 2014). SCT in entrepreneurship posits that the positive attitude of others towards the entrepreneur can lead to improved access to information and knowledge, 
power or influence over other actors, and a sense of belonging or solidarity (Aldrich and Zimmer 1986; de Carolis et al. 2009; Walker et al. 1997). Although positive consequences have been the primary focus of research, recently there has been some attention on the negative consequences of social capital (Kautonen et al. 2010). Negative consequences include high opportunity costs of maintaining the relationships and the risk of groupthink (Adler and Kwon 2002; Portes 1998).

Social capital is embedded in the relationship with others (Nahapiet and Ghoshal 1998). Therefore, the characteristics of these relationships determine the level of social capital. We discuss three dimensions (Hoang and Antoncic 2003; Nahapiet and Ghoshal 1998; Stam et al. 2014). First, the structural dimension refers to the position of the actor in the network (Nahapiet and Ghoshal 1998). This position is characterised by the extent to which the relationships of an actor are mutually connected. It influences social capital in two contrasting ways. Firstly, when the relationships of an actor are heavily connected, there is a high level of 'closure' (Coleman 1988). As a result, the social capital of the actor increases due to the trust and social support among its relationships impeding opportunistic behaviour (Ahuja 2000; Uzzi 1997). In the contrasting case of limited closure, the social capital of the actor increases due to the access to unique information from its relationships with actors that are otherwise not connected (Burt 2004). Both ways have been associated with firm performance, but for start-ups the limited closure has a stronger effect (Stam et al. 2014).

Secondly, the relational dimension of social capital refers to the strength of the relationship (Granovetter 1973; Nahapiet and Ghoshal 1998). Relationally strong ties are emotionally underpinned, intimate and include friendships, gratitude and respect (Granovetter 1973). These ties are reliable, imply a high level of trust and induce favours, but are costly to maintain. Relationally weak ties are valuable because they are relatively cheap to maintain and they usually connect actors in different contexts holding different information. These facilitate access to a combination of new, non-redundant pieces of information (Granovetter 1973; Powell et al. 1996). Therefore both weak and strong ties can result in social capital benefits and so, for start-ups, it has been argued that a balanced proportion between weak and strong ties is important (Stam et al. 2014; Uzzi 1997).

The third dimension of social capital entails the homophily dimension (Nahapiet and Ghoshal 1998; Ruef et al. 2003). This dimension refers to how similar the two actors are in terms of what they know, have and think (Stam et al. 2014). The homophily dimension of the relationship is again argued to influence social capital in two contrasting ways. On the one hand, benefits from social capital accrue from a high degree of homophily because of high reciprocal understanding (Ruef et al. 2003). On the other hand, social capital accrues from a low degree of homophily because these contacts provide access to alternative resources and alternative cognitive interpretations (Birley 1985; Nahapiet and Ghoshal 1998). For start-ups in high-tech industries, a low degree of homophily is more strongly associated with performance (Stam et al. 2014).

\subsubsection{Reviewing the network-based incubation literature}

Turning to the network-based incubation literature, 12 articles take on a SCT perspective. ${ }^{9}$ From this perspective, network-based incubation is seen as an environment in which social capital is built between actors in the network. Social capital then contributes to the start-

\footnotetext{
9 An article uses the SCT perspective when it explicitly states so, or when major constructs from the theory are focused on in a way congruent with the SCT perspective.
} 
up's influence, resources, information and knowledge. These advantages can then improve start-up performance.

The network is measured both metaphorically (six articles) and analytically (six articles)—metaphorically by, for example, qualitatively distinguishing between advisory networks and funding networks (Sá and Lee 2012) and analytically by, for example, measuring the existence of direct and indirect ties with suppliers and customers (Ebbers 2013). Network-based incubation affects the social capital of the start-up along the three dimensions introduced in the previous section. Firstly, incubation influences the structural dimension of social capital by stimulating and helping the start-up to form relationships with other actors (eight articles). The network-based incubation literature has identified two practices, both increasing the network closure. Firstly, physical proximity, shared spaces and social events induce relationship formation among the actors in the internal network (Bøllingtoft and Ulhøi 2005; Tötterman and Sten 2005). This results in a denser internal network and hence more closure. Secondly, network-based incubation also involves an external network. This network is usually developed and maintained by the incubation manager (Hansen et al. 2000). Hence, when incubated start-ups connect to these actors, it adds to the number of relationships in the external network, also increasing closure (Scillitoe and Chakrabarti 2010; Tötterman and Sten 2005). As a result, networkbased incubation clearly adds to the 'closure' of the internal and external network, improving the sense of belonging and trust for incubated start-ups. The network-based incubation literature has not identified practices decreasing closure (for example, by encouraging start-ups to terminate certain relationships).

Secondly, seven articles discuss how network-based incubation affects the relational dimension of the start-up's social capital. Network-based incubation fosters a trusting, interactive and sharing culture, inducing strong ties among start-ups (Bøllingtoft and Ulhøi 2005; Sá and Lee 2012; Tötterman and Sten 2005) and between the start-up and the incubator manager (Fang et al. 2010; Scillitoe and Chakrabarti 2010). Besides these strong ties, network-based incubation helps start-ups develop weak ties. This is done by organising networking events at which start-ups can meet new actors (Patton and Marlow 2011; Sá and Lee 2012).

Finally, three articles studying the homophily dimension of social capital find that in the relationship with other start-ups, neither a too high nor a too low degree of homophily is optimal for creating a high level of social capital. If start-ups are very different, they do not understand each other well. If they are too similar, this leads to conflicting interests and overlapping information. This implies an in-between optimal balance of homophily, which is theoretically acknowledged but empirically difficult to evaluate. Incubators vary in the extent to which they maximise the homogeneity of the group of start-ups (Schwartz and Hornych 2010). Through candidate selection and the internal culture, some incubation programmes focus on creating a homogeneous group of start-ups, while others select a more diverse group of start-ups (Bøllingtoft and Ulhøi 2005; Sá and Lee 2012; Tötterman and Sten 2005).

From an SCT perspective, five articles measure the social capital in relation to start-up performance. Four do that subjectively (namely, the achievement of entrepreneurial goals, competitive performance, survival and capability building) and one objectively (average annual job growth). An increase in the structural dimension of the social capital of the start-up is found to positively influence the start-up's innovative and market performance (Hughes et al. 2007; Scillitoe and Chakrabarti 2010). The relational social capital embedded in the relationship with the incubator manager is also positively associated with start-up performance in terms of capability improvement (Fang et al. 2010), competitive 
performance (Hughes et al. 2007) and venture development and growth (Scillitoe and Chakrabarti 2010). The incubator manager has valuable and complementary information to help the start-up. In contrast, the relational social capital through strong ties with other start-ups is not associated with performance improvements, as start-ups find it challenging to capitalise on these relationships (Bøllingtoft and Ulhøi 2005; Sá and Lee 2012; Tötterman and ten 2005). Start-ups have similar information and benefit less from sharing this. Qualitative research has suggested an inverted u-shape between the homophily dimension of relationships among start-ups and performance. That is to say, start-ups are only able to benefit from each other if they are somewhat similar (Schwartz and Hornych 2010). However, if start-ups are too similar, they are more prone to be the victim of actions by other start-ups, such as theft of intellectual property or valuable network contacts. As a result, they will be secretive and unable to benefit from one another (McAdam and Marlow 2007). Nevertheless, this hypothesised inverted u-shape is not investigated quantitatively.

\subsubsection{Reflection and further research}

The literature shows that network-based incubation increases the social capital of start-ups over all three dimensions. Social capital is embedded in the relationship between actors. Incubated start-ups develop relationships with other start-ups, the incubator manager, mentors, financiers and other actors. How the social capital embedded in these different relationships then relates to start-up performance is less clear. This incomplete understanding can be attributed to the preoccupancy of current research with the positive effects of social capital. Negative effects of social capital have largely been overlooked. In certain cases, these negative effects may outweigh the positive effects, resulting in an overall negative impact. For example, start-ups that are preoccupied with maintaining too many relationships might be distracted from pursuing their business idea in a focused manner. Alternatively, having a tight network might limit the start-up from looking beyond the usual actors in their network for help. Omitting the negative consequences of social capital might explain the contradictory evidence found in network-based incubation impact studies. Therefore, for further research we advocate the inclusion of the possible negative consequences of social capital in the analysis.

\section{Synthesis and research agenda}

Thus far we have reviewed the network-based incubation literature separately through the lenses of three management theories. Table 2 summarises these findings. The table is structured according to the main categories of the review and is extended with categories that further emerged from the data. Predefined conceptual categories are performance measures, network approach and theoretical mechanisms. The categories that emerged from the data are network-based incubation practices, performance impact, and reflections and further research. Accordingly, we discuss the network-based incubation literature across the theoretical perspectives to arrive at overarching insights.

Studies use a broad variety of performance measures, but these are quite similar between the theories. This is partly the consequence of the fact that some articles combine theoretical perspectives, such as SCT and RBV in Hughes et al. (2007). However, across all studies, most performance measures are used only once or twice. This is problematic, as it inhibits comparison and generalisability across specific empirical situations. The paucity 


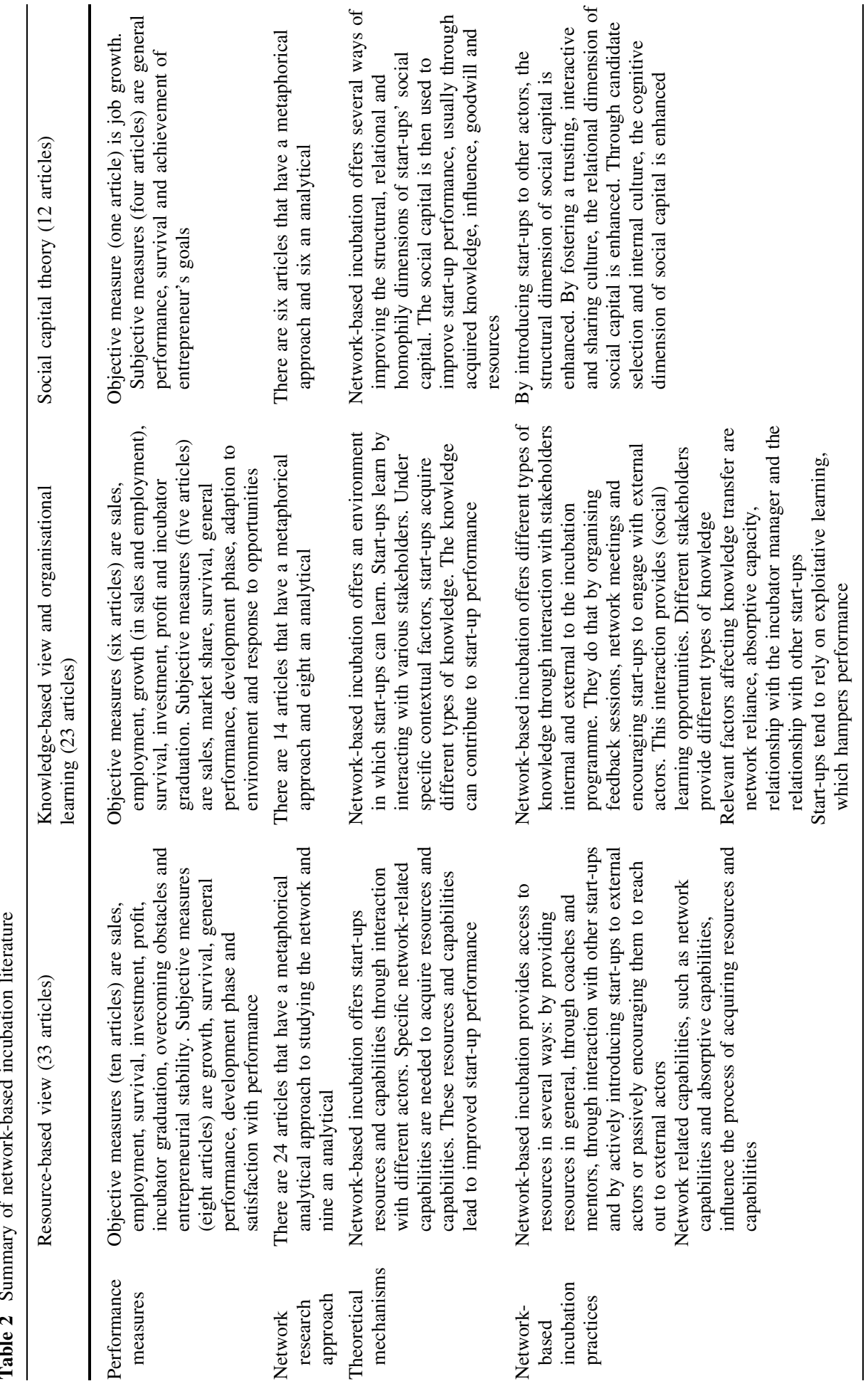




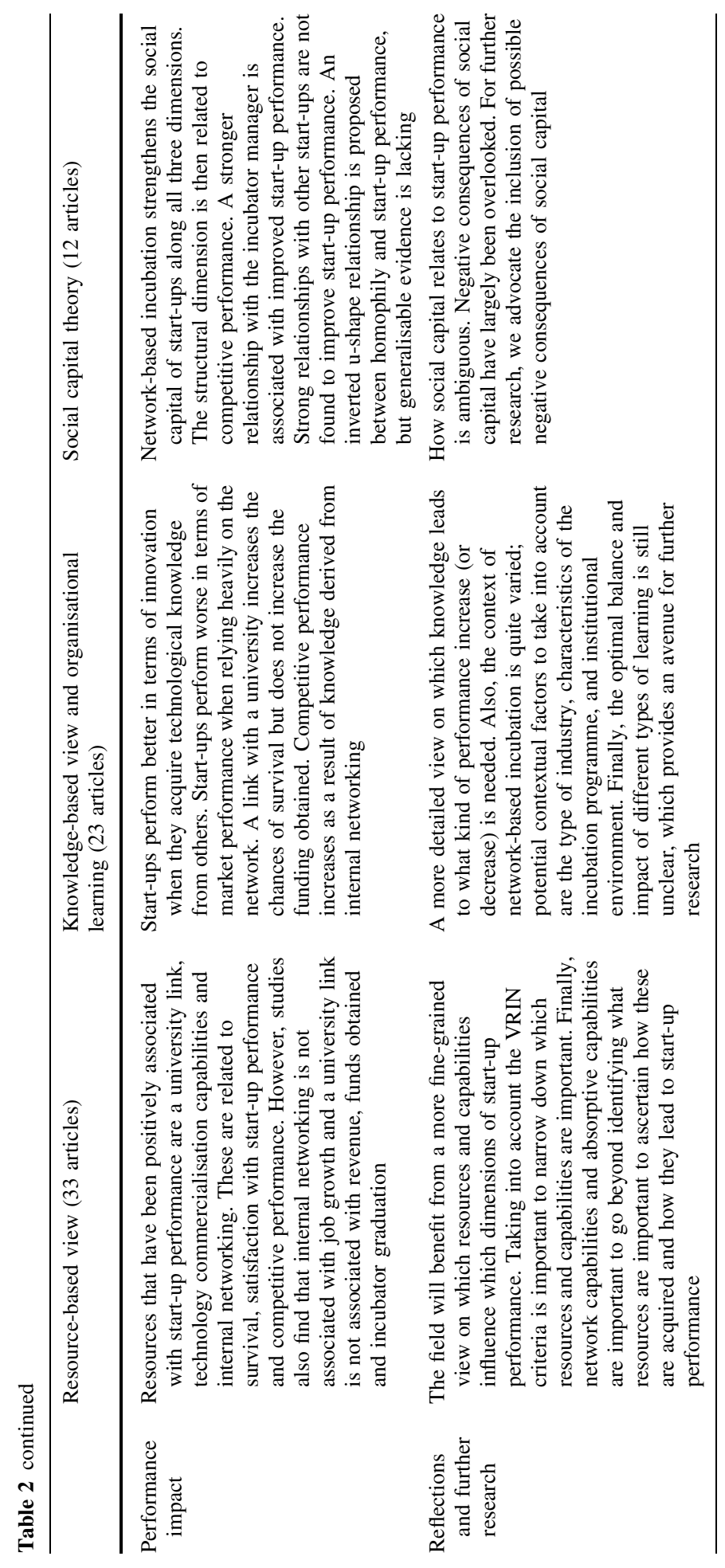


of studies using similar performance measures thereby hampers the development of a more nuanced view of network-based incubation.

In the network-based incubation literature, the network is mainly approached metaphorically across the different theoretical perspectives. About half the articles employing SCT use more analytical approaches, but for RBV and KBV/OL, this is considerably reduced. A metaphorical approach can be very useful in a qualitative context, as it facilitates uncovering the theoretical mechanisms through which network-based incubation affects start-up performance. However, an analytical approach is important for understanding the relative importance of these mechanisms and to generalise results.

The theoretical mechanisms differ between the theoretical perspectives. An obvious difference is the 'intermediary benefit' that is taken into account. For RBV, these are resources and capabilities; for KBV and OL, these are knowledge and learning; and for SCT, the intermediary benefit is social capital. The theoretical mechanisms from different perspectives feed into each other. Articles adopting a SCT approach often focus on how start-ups develop relationships, thereby providing insight into the preconditions for exchanging resources (RBV), sharing knowledge and social learning (KBV and OL). Furthermore, startups need network capabilities (RBV) to develop relationships with others and position themselves structurally in the internal and external network (SCT). Furthermore, networkbased incubation induces strong ties among actors (SCT) and, through these strong ties, tacit knowledge can be exchanged between the start-up and other actors (KBV). Moreover, the homophily dimension of relationships is determined by network-based incubation through start-up candidate selection (SCT). This feeds into the mechanism of absorptive capacity, which determines the exchange of knowledge between actors (KBV).

The literature identifies three archetypal network-enhancing incubation practices regardless of the theoretical perspectives adopted. Firstly, network-based incubation provides networking opportunities with fellow incubated start-ups. It does this by selecting the candidates carefully, having open building designs and by fostering a trusting culture. Secondly, network-based incubation entails the development of relationships with the incubator manager and internal mentors. These relationships are strengthened in routine coaching sessions. Thirdly, network-based incubation offers introductions and network opportunities with actors outside the programme. The network of the incubator manager and coaches outside the incubation organisation is particularly important. The choice of theoretical perspective does not affect which practices are identified. However, depending on the chosen theoretical perspective, different types of benefits are identified, such as certain resources, knowledge or certain levels of social capital.

Turning to the impact on start-up performance, the review shows that network-based incubation clearly leads to intermediary benefits for the start-ups: resources, capabilities, knowledge, learning and social capital. Many studies then simply assume that more 'intermediary benefits' will automatically lead to enhanced start-up performance. However, the empirical evidence for this assumption is tenuous. From different theoretical perspectives, there are intermediary benefits associated both with performance increase and with performance decrease. The use of performance measures is too varied to formally compare and weigh the relative impact of the intermediary benefits.

\subsection{Reflection and further research}

We have discussed suggestions for further research from the three theoretical perspectives in the subsections of the findings section. Recapitulating these suggestions, the networkbased incubation literature can benefit from contemporary insights and concepts from the 
management theories, such as VRIN criteria and network capabilities from the RBV, the contextual factors for knowledge exchange and learning from KBV and OL, and negative consequences of social capital from SCT. We have identified these concepts as being promising directions for further research. Furthermore, the three theories hold many other interesting, leading-edge ideas from which network-based incubation literature can potentially benefit, such as resource orchestration (Sirmon et al. 2010), dynamic capabilities (Teece et al. 1997) and experiential learning (Corbett 2005). However, because these ideas have not been applied in the network-based incubation literature, they could not be included in this review.

Furthermore, we identified numerous but sporadically applied performance measures, and noted that the implications of studies are heavily dependent on the measures used. We argue therefore that the network-based incubation literature needs to adopt a broad and recurring set of performance measures. We suggest a combination of objective (e.g. employment, revenue) and subjective (e.g. achievement of goals, satisfaction) performance measures, both related to the current situation (e.g. revenue) and future potential (e.g. funds obtained). For now, we have limited our analysis to those performance measures that are discussed both in management theories and in network-based incubation literature. Additional measures of performance may also be interesting, such as entrepreneurial welfare.

Moreover, we have shown that the relative importance of network-based incubation practices is difficult to assess when the start-up network is not approached analytically. This hampers determination of the strength of the influence of the network-based incubation on a start-up's network, and the strength of the influence of the start-up's network on start-up performance. Therefore, we argue that further research should apply more analytical network approaches.

Finally, further research has the task of developing a finer-grained model of the impact of network-based incubation on start-up performance. This model needs to go beyond the taken-for-granted assumption that the benefits from network-based incubation improve start-up performance in general. It should explain and predict how specific intermediary benefits derived from network-based incubation lead to a change in specific performance dimensions. We call for further research to continue assessing the impact of specific intermediary benefits on start-up performance measures.

\section{Conclusion and implications}

The overall aim of this review was to analyse the empirical evidence on the influence of network-based incubation on start-up performance through the lenses of three management theories. We found several network-based incubation practices and discussed the theoretical mechanisms through which these practices lead to intermediary benefits for start-ups. While it is clear that network-based incubation leads to intermediary benefits for start-ups, the relative importance of the network-based incubation practices is unclear. Furthermore, the influence of intermediary benefits on start-up performance is ambiguous. Intermediary benefits, such as resources, knowledge, learning and social capital, can both improve and worsen start-up performance, depending on the particular type of benefit and the performance measure used. A research agenda has been proposed to overcome these limitations and advance the field.

Thereby we have contributed to solving the two main shortcomings in the field of network-based incubation literature identified in the introduction. Firstly, we have shed light on the seemingly contradictory results in the network-based incubation literature. The review shows that the articles that find a positive influence of network-based incubation on 
performance (Hansen et al. 2000; Hughes et al. 2007; Patton 2014) identify different incubation practices and use different performance measures from the articles that are much more critical (Oakey 2007; Soetanto and Jack 2013). Therefore we argue for a finergrained model of the impact of network-based incubation to advance the field. To arrive at such a model, this review has started by identifying and specifying the influence of intermediary benefits on start-up performance.

Secondly, by reviewing the literature against the background of management theories, we reply to the call to increase the theoretical depth of the network-based incubation literature (Ahmad and Ingle 2013; Amezcua et al. 2013; Hackett and Dilts 2004). This review has shown which and how contemporary concepts and insights from the resourcebased view, from the knowledge-based view and organisational learning, and from social capital theory can strengthen the network-based incubation literature.

This review has limited itself to the theoretical perspectives that were most apparent in the network-based incubation literature. We acknowledge that with additional perspectives a fuller understanding of the networked incubation phenomenon can be achieved. In particular, it would facilitate a more contextual approach to network-based incubation (Ács et al. 2014; Autio et al. 2014; Welter 2011; Zahra et al. 2014). However, currently there are too few articles that use these theoretical perspectives to include these perspectives in this review. Other interesting theoretical perspectives that have been suggested are the resource dependency view (e.g. Amezcua et al. 2013; Phan et al. 2005), institutional theory (e.g. Hackett and Dilts 2004; Phan et al. 2005; Rothschild and Darr 2005), innovation systems literature (e.g. Hu et al. 2006) and cluster theory (e.g. Chan and Lau 2005). These alternative theories open up opportunities to assess the influence of network-based incubation on performance measures at the regional level, such as innovation, employment and economic growth.

The take-away message for policymakers, incubation practitioners, start-up founders and other stakeholders is that network-based incubation is not a panacea for solving all start-ups' problems. While network-based incubation can provide several benefits, these 'benefits' can lead to both positive and negative consequences. The results of this review suggest that the match between the requirements and aims of the start-up and the offerings of network-based incubation needs to be taken into account to maximise performance increase. Growth, entrepreneurial satisfaction and profitability are all valid goals for the start-up, but assisting start-ups to achieve these goals likely requires very different practices. Furthermore, because the choice of performance measure is pivotal to evaluate the impact of network-based incubation, it is advisable for incubation practitioners and policymakers to keep track of a broad range of performance measures and to compare them across incubation initiatives.

Acknowledgments This research was funded by Climate-Knowledge and Innovation Community (ClimateKIC), part of the European Institute of Technology under the European Commission. We would like to thank Ali Ahmad and Sarah Jack for providing valuable comments on earlier versions of this article.

Open Access This article is distributed under the terms of the Creative Commons Attribution 4.0 International License (http://creativecommons.org/licenses/by/4.0/), which permits unrestricted use, distribution, and reproduction in any medium, provided you give appropriate credit to the original author(s) and the source, provide a link to the Creative Commons license, and indicate if changes were made.

\section{Appendix}

See Table 3. 


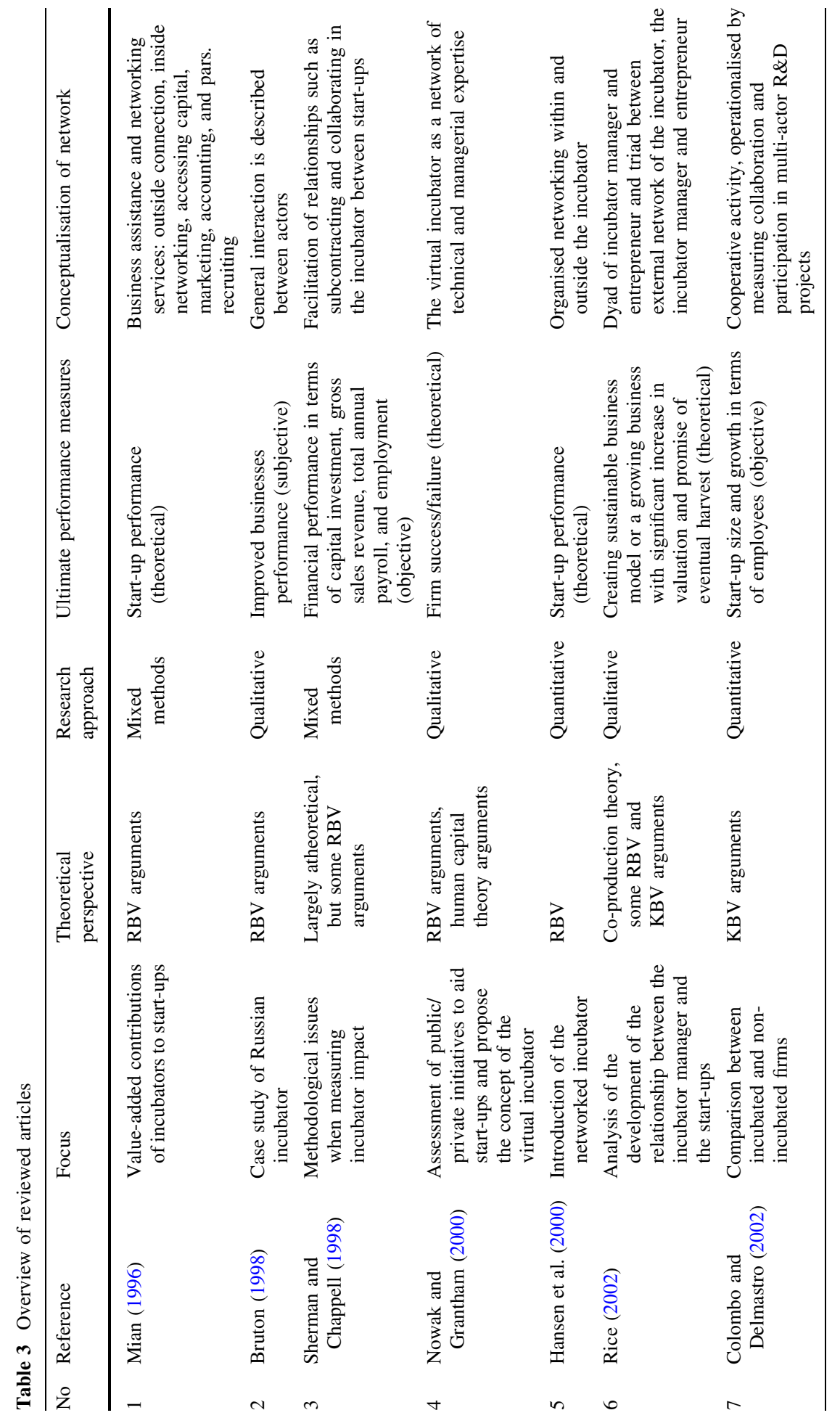




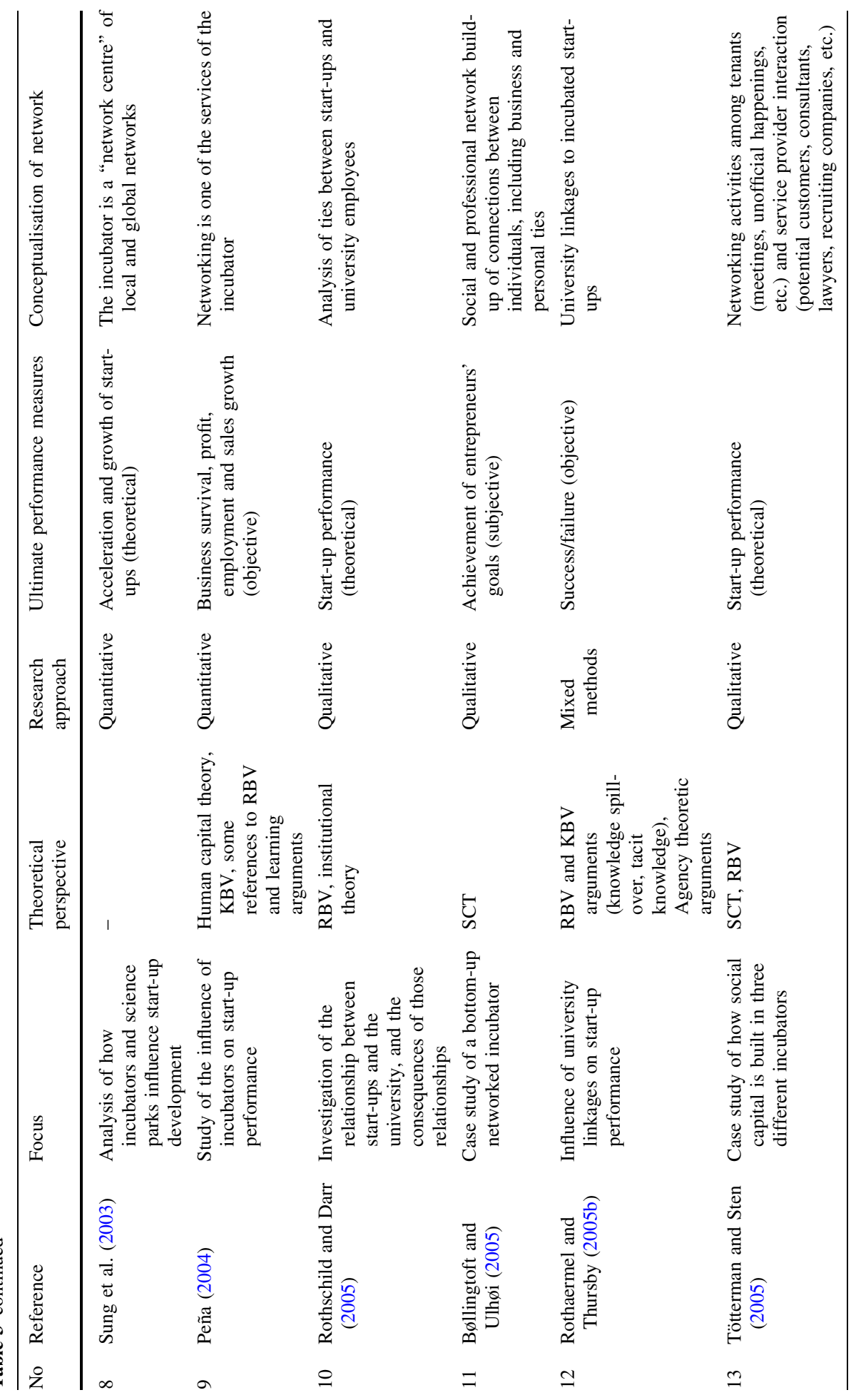




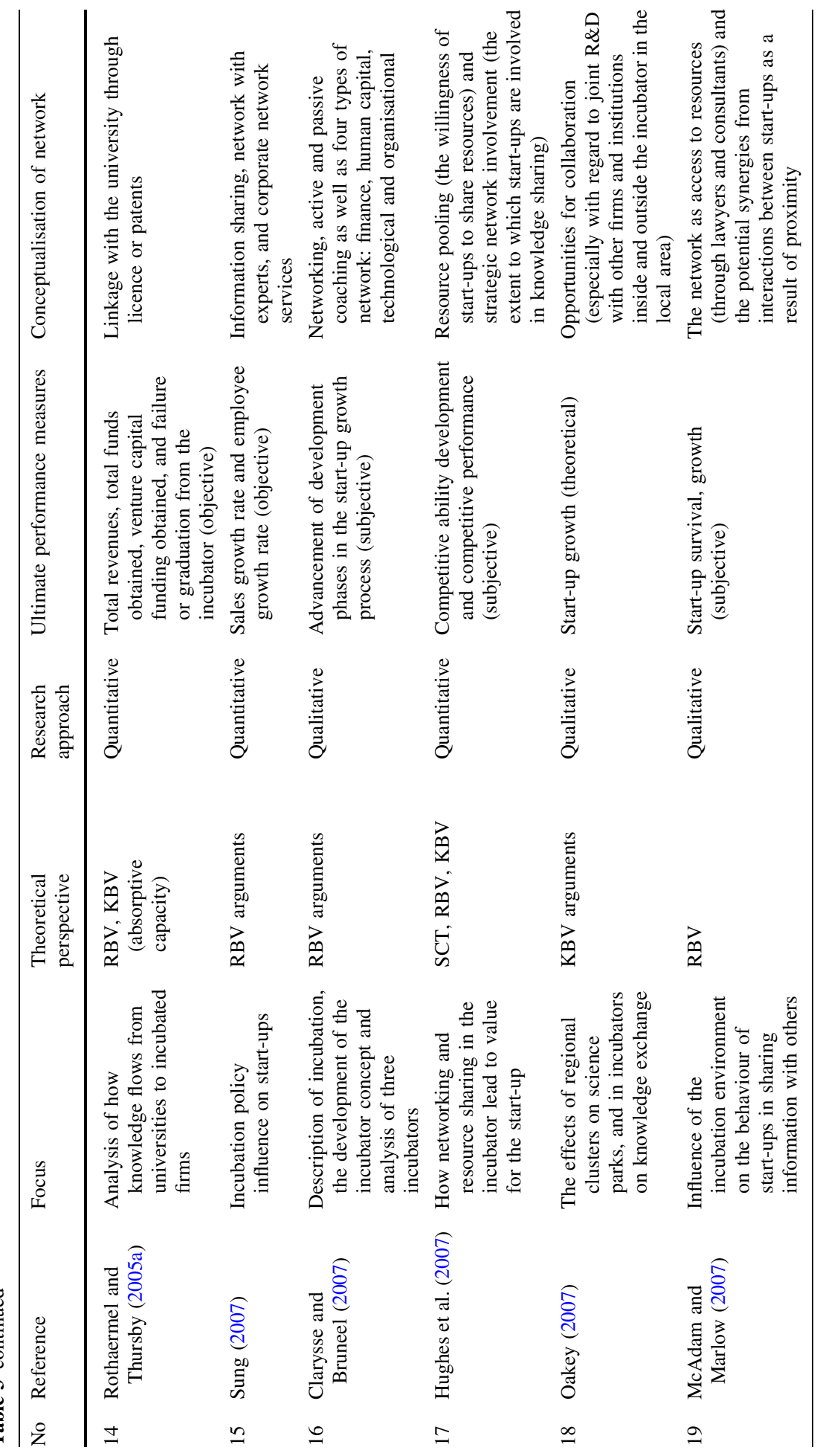




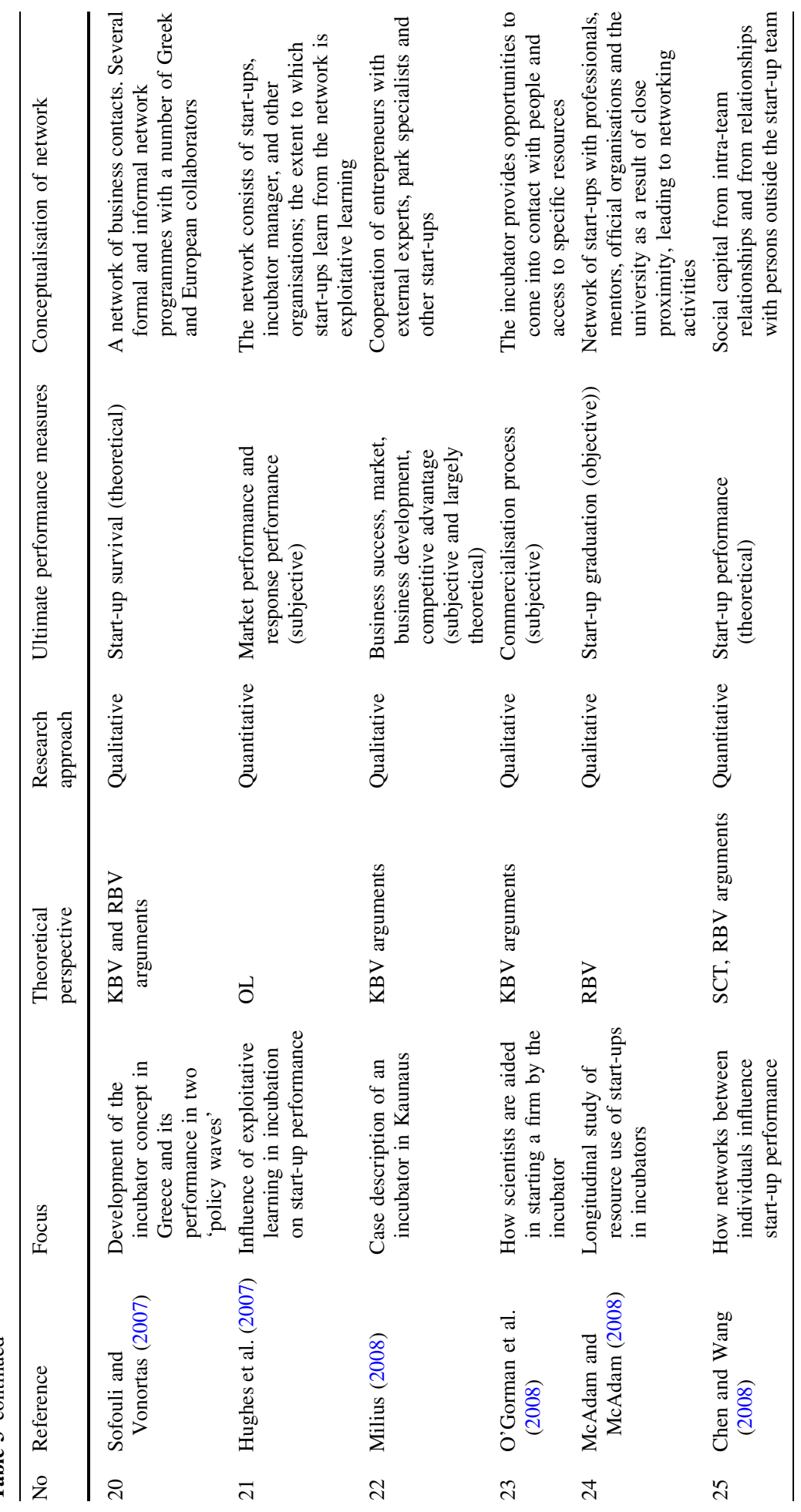




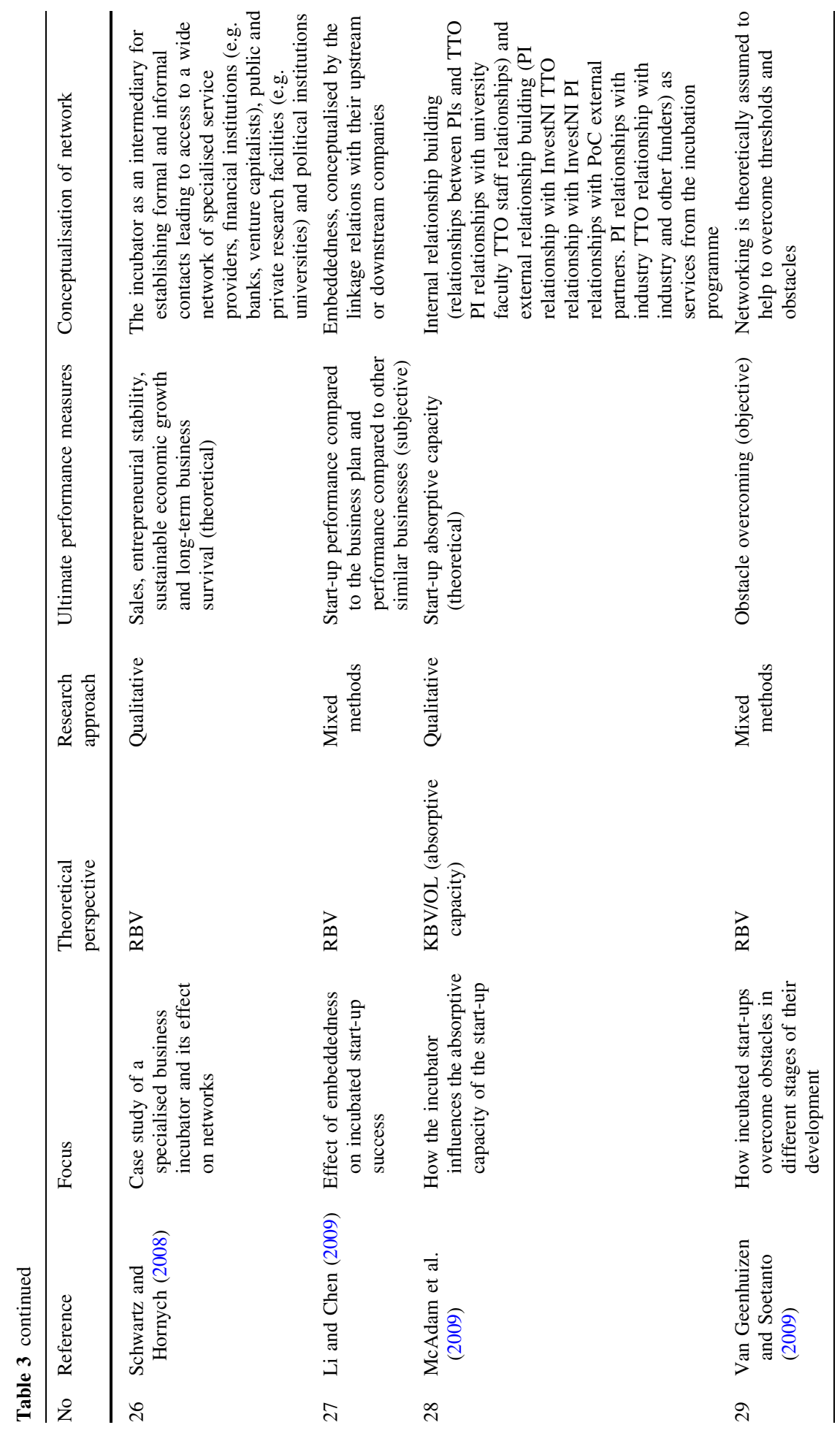




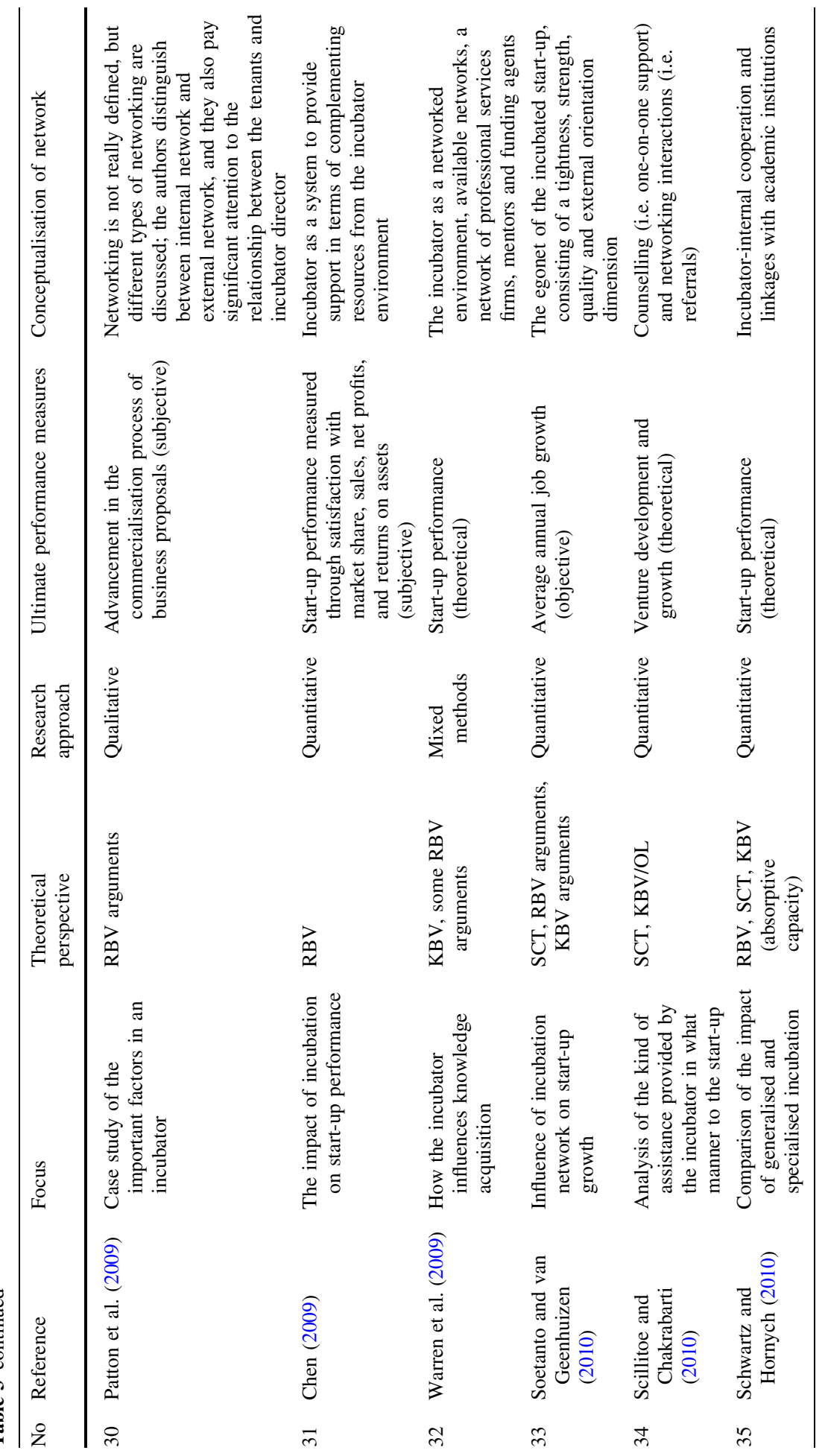




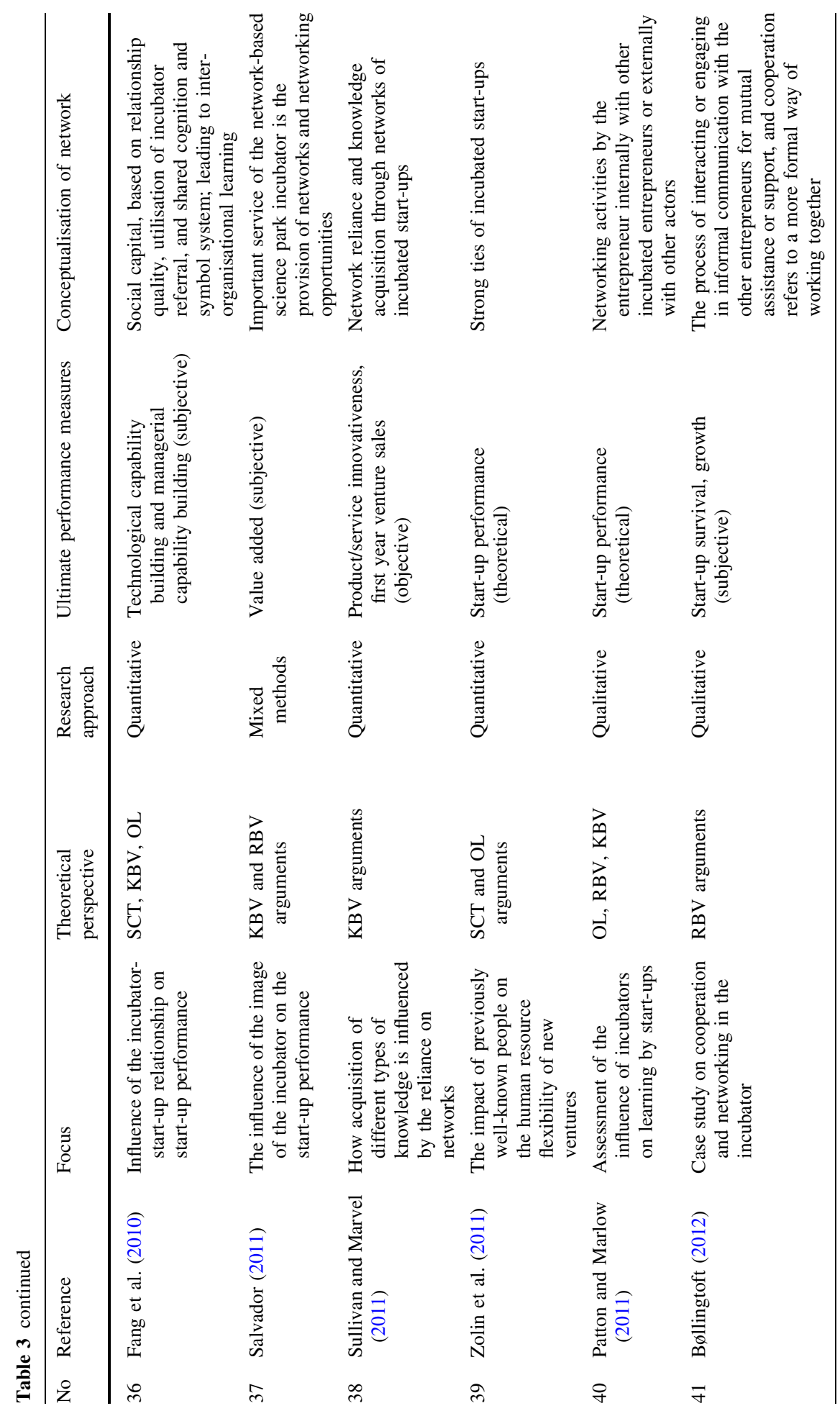




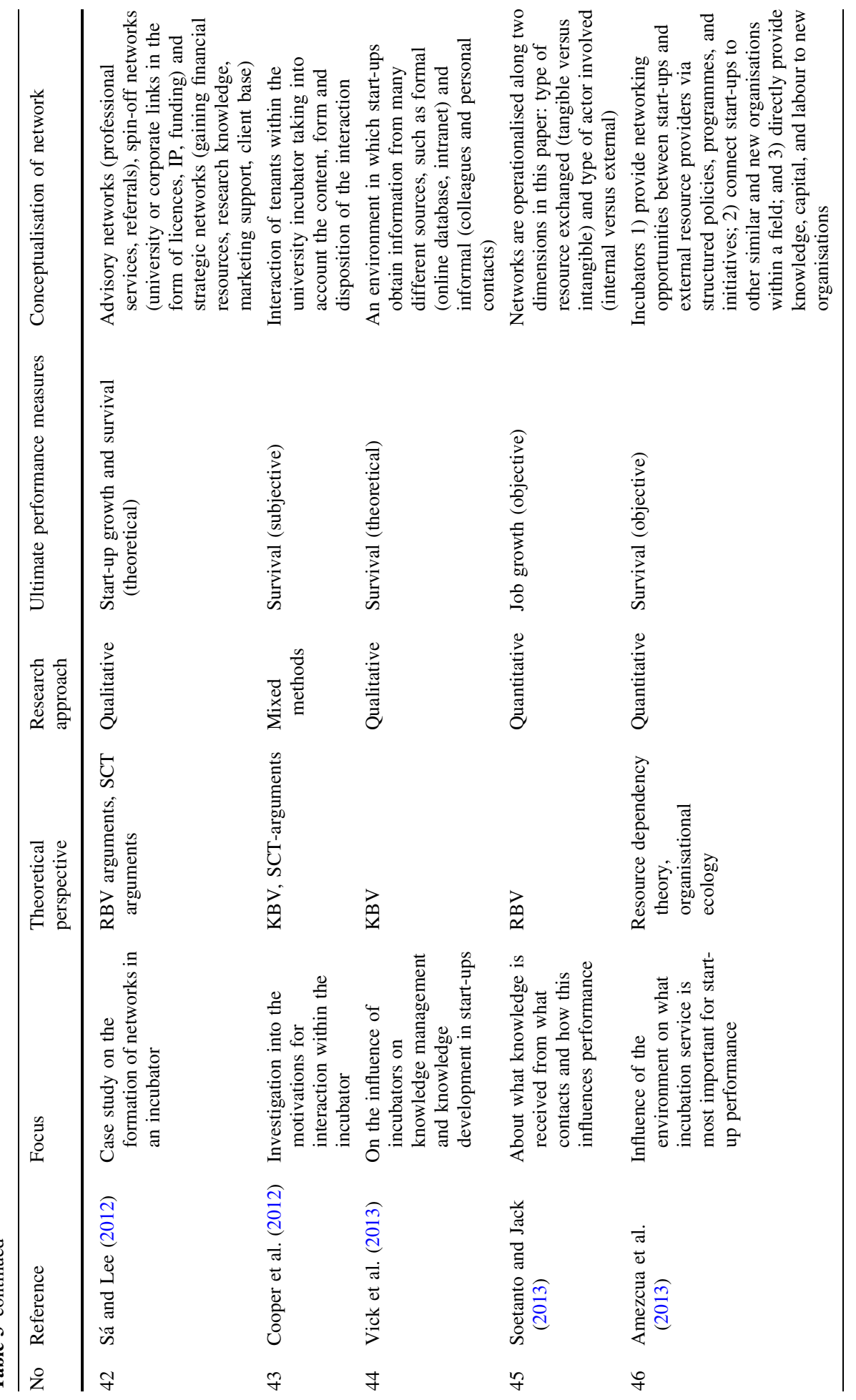




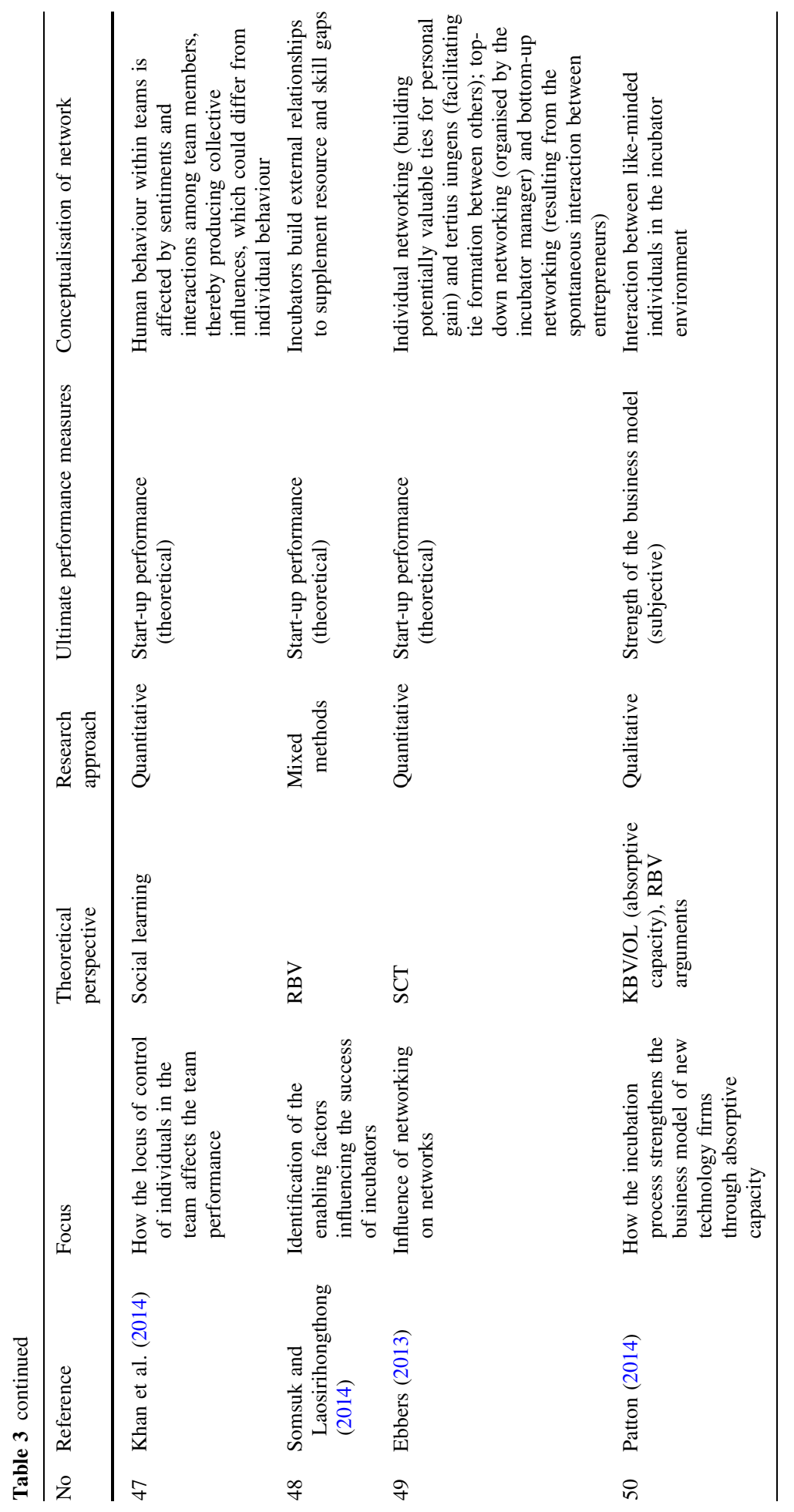




\section{References}

Ács, Z. J., Autio, E., \& Szerb, L. (2014). National systems of entrepreneurship: Measurement issues and policy implications. Research Policy, 43(3), 476-494. doi:10.1016/j.respol.2013.08.016.

Adler, P. S., \& Kwon, S.-W. (2002). Social capital: Prospects for a new concept. Academy of Management Review, 27(1), 17-40.

Aernoudt, R. (2004). Incubators: Tool for entrepreneurship? Small Business Economics, 23(2), 127-135. doi:10.1023/B:SBEJ.0000027665.54173.23.

Ahmad, A. J., \& Ingle, S. (2011). Relationships matter: Case study of a university campus incubator. International Journal of Entrepreneurial Behaviour \& Research, 17(6), 626-644. doi:10.1108/ 13552551111174701 .

Ahmad, A., \& Ingle, S. (2013). Business incubators and HTSF development: Setting an agenda for further research. In R. Oakey, A. Groen, C. Cook, \& P. Van Der Sijde (Eds.), New technology-based firms in the new millenium (Vol. 10, pp. 119-140). Bingley: Emerald Group Publishing Limited.

Ahuja, G. (2000). Collaboration networks, structural holes, and innovation: Longitudinal study Gautam Ahuja. Administrative Science Quarterly, 45(3), 425-455.

Aldrich, H., \& Zimmer, C. (1986). Entrepreneurship through social networks. In D. L. Sexton \& R. W. Smilor (Eds.), The art and science of entrepreneurship (pp. 3-23). Cambridge, MA: Ballinger.

Amezcua, A. S., Grimes, M. G., Bradley, S. W., \& Wiklund, J. (2013). Organizational sponsorship and founding environments: A contingency view on the survival of business-incubated firms, 1994-2007. Academy of Management Journal, 56(6), 1628-1654. doi:10.5465/amj.2011.0652.

Amit, R., \& Schoemaker, P. J. H. (1993). Strategic assets and organizational rent. Strategic Management Journal, 14(1), 33-46.

Autio, E., Kenney, M., Mustar, P., Siegel, D., \& Wright, M. (2014). Entrepreneurial innovation: The importance of context. Research Policy, 43(7), 1097-1108. doi:10.1016/j.respol.2014.01.015.

Bandura, A. (1977). Social learning theory. Upper Saddle River, NJ: Prentice Hall.

Barney, J. B. (1991). Firm resources and sustained competitive advantage. Journal of Management, 17(1), 99-120. doi:10.1177/014920639101700108.

Barney, J. B. (2001). Resource-based theories of competitive advantage: A ten-year retrospective on the resource-based view. Journal of Management, 27(6), 643-650. doi:10.1177/014920630102700602.

Baron, R. A., Mueller, B. A., \& Wolfe, M. T. (2016). Self-efficacy and entrepreneurs' adoption of unattainable goals: The restraining effects of self-control. Journal of Business Venturing, 31(1), 55-71. doi:10.1016/j.jbusvent.2015.08.002.

Bergenholtz, C., \& Waldstrøm, C. (2011). Inter-organizational network studies-A literature review. Industry \& Innovation, 18(6), 539-562. doi:10.1080/13662716.2011.591966.

Bergh, P., Thorgren, S., \& Wincent, J. (2009). Entrepreneurs learning together: The importance of building trust for learning and exploiting business opportunities. International Entrepreneurship and Management Journal, 7(1), 17-37. doi:10.1007/s11365-009-0120-9.

Birley, S. (1985). The role of networks in the entrepreneurial process. Journal of Business Venturing, 7, $107-117$.

Blyler, M., \& Coff, R. W. (2003). Dynamic capabilities, social capital, and rent appropriation: Ties that split pies. Strategic Management Journal, 24(7), 677-686. doi:10.1002/smj.327.

Bøllingtoft, A. (2012). The bottom-up business incubator: Leverage to networking and cooperation practices in a self-generated, entrepreneurial-enabled environment. Technovation, 32(5), 304-315. doi:10.1016/ j.technovation.2011.11.005.

Bøllingtoft, A., \& Ulhøi, J. P. (2005). The networked business incubator-Leveraging entrepreneurial agency? Journal of Business Venturing, 20(2), 265-290. doi:10.1016/j.jbusvent.2003.12.005.

Brüderl, J., \& Preisendörfer, P. (1998). Network support and the success of newly founded businesses. Small Business Economics, 10, 213-225.

Bruneel, J., Ratinho, T., Clarysse, B., \& Groen, A. (2012). The evolution of business incubators: Comparing demand and supply of business incubation services across different incubator generations. Technovation, 32(2), 110-121. doi:10.1016/j.technovation.2011.11.003.

Brush, C. G., \& Vanderwerf, P. A. (1992). A comparison of methods and sources for obtaining estimates of new venture performance. Journal of Business Venturing, 7, 157-170.

Bruton, G. D. (1998). Incubators as a small business support in Russia: Contrast of university-related U.S. incubators. Journal of Small Business Management, 36, 91-94.

Burgers, J. H., Van Den Bosch, F. A. J., \& Volberda, H. W. (2008). Why new business development projects fail: Coping with the differences of technological versus market knowledge. Long Range Planning, 41, 55-73. doi:10.1016/j.1rp.2007.10.003. 
Burt, R. S. (2000). The network structure of social capital. Research in Organizational Behavior, 22, $345-423$.

Burt, R. S. (2004). Structural holes and good ideas. American Journal of Sociology, 110(2), 349-399.

Cantner, U., \& Graf, H. (2006). The network of innovators in Jena: An application of social network analysis. Research Policy, 35, 463-480.

Chan, K. F., \& Lau, T. (2005). Assessing technology incubator programs in the science park: The good, the bad and the ugly. Technovation, 25(10), 1215-1228. doi:10.1016/j.technovation.2004.03.010.

Chandler, G. N., \& Hanks, S. H. (1993). Measuring the performance of emerging businesses: A validation study. Journal of Business Venturing, 8(5), 391-408. doi:10.1016/0883-9026(93)90021-V.

Chen, C.-J. (2009). Technology commercialization, incubator and venture capital, and new venture performance. Journal of Business Research, 62(1), 93-103. doi:10.1016/j.jbusres.2008.01.003.

Chen, M.-H., \& Wang, M.-C. (2008). Social networks and a new venture's innovative capability: The role of trust within entrepreneurial teams. R\&D Management, 38(3), 253-264.

Clarysse, B., \& Bruneel, J. (2007). Nurturing and growing innovative start-ups: The role of policy as integrator. R\&D Management, 37(2), 139-149. doi:10.1111/j.1467-9310.2007.00463.x.

Clarysse, B., Wright, M., Lockett, A., Van de Velde, E., \& Vohora, A. (2005). Spinning out new ventures: A typology of incubation strategies from European research institutions. Journal of Business Venturing, 20(2), 183-216. doi:10.1016/j.jbusvent.2003.12.004.

Cohen, W. M., \& Levinthal, D. A. (1990). Absorptive capacity: A new perspective on learning and innovation. Administrative Science Quarterly, 35(1), 128-152.

Coleman, J. S. (1988). Social capital in the creation of human capital. American Journal of Sociology, 94, S95-S120.

Colombo, M. G., \& Delmastro, M. (2002). How effective are technology incubators? Evidence from Italy. Research Policy, 31, 1103-1122.

Cooper, A. C. (1993). Challenges in predicting new firm performance. Journal of Business Venturing, 8(October 1991), 241-253.

Cooper, C. E., Hamel, S. A., \& Connaughton, S. L. (2012). Motivations and obstacles to networking in a university business incubator. Journal of Technology Transfer, 37(4), 433-453. doi:10.1007/s10961010-9189-0.

Corbett, A. C. (2005). Experiential learning within the process of opportunity identification and exploration. Entrepreneurship Theory and Practice, 29(4), 473-491.

Cowan, R., David, P. A., \& Foray, D. (2000). The explicit economics of knowledge codification and tacitness. Industrial and Corporate Change, 9, 211-253. doi:10.1093/icc/9.2.211.

Crook, T. R., Ketchen, D. J., Combs, J. G., \& Todd, S. Y. (2008). Strategic resources and performance: A meta-analysis. Strategic Management Journal, 29, 1141-1154. doi:10.1002/smj.703.

Crossan, M., Lane, H., \& White, R. (1999). An organizational learning framework: From intuition to institutions. Academy of Management Review, 24(3), 522-537.

de Carolis, D. M., Litzky, B. E., \& Eddleston, K. A. (2009). Why networks enhance the progress of new venture creation: The influence of social capital and cognition. Entrepreneurship: Theory and Practice, doi:10.1080/00365510903137237.

Dierickx, I., \& Cool, K. (1989). Asset stock accumulation and sustainability of competitive advantage. Management Science, 35(12), 1504-1511.

Dodgson, M. (1993). Organizational learning: A review of some literatures. Organization Studies, 14(3), 375-394.

Duff, A. (1994). Best practice in business incubator management. Kensington: Booragoon.

Dutta, S., \& Folta, T. B. (2016). A comparison of the effect of angels and venture capitalists on innovation and value creation. Journal of Business Venturing, 31(1), 39-54. doi:10.1016/j.jbusvent.2015.08.003.

Dyer, J. H., \& Singh, H. (1998). The relational view: Cooperative strategy and sources of interorganizational competitive advantage. Academy of Management Review, 23(4), 660-679.

Easterby-Smith, M., Crossan, M., \& Nicolini, D. (2000). Organizational learning: Debates past, present and future. Journal of Management Studies, 37(6), 783-796.

Ebbers, J. J. (2013). Networking behavior and contracting relationships among entrepreneurs in business incubators. Entrepreneurship: Theory and Practice, doi:10.1111/etap.12032.

Fahy, J. (2000). The resource-based view of the firm: Some stumbling-blocks on the road to understanding sustainable competitive advantage. Journal of European Industrial Training, 24(2-4), 94-104.

Fang, S.-C., Tsai, F.-S., \& Lin, J. L. (2010). Leveraging tenant-incubator social capital for organizational learning and performance in incubation programme. International Small Business Journal, 28(1), 90-113. doi:10.1177/0266242609350853.

Fernández, M. (2012). Promotion of social entrepreneurship through public services in the Madrid region: Successful aspects. Amfiteatru Economic, XIV, 774-785. 
Fiol, C. M., \& Lyles, M. A. (1985). Organizational learning. The Academy of Management Review, 10(4), 803-813.

Garnsey, E., Stam, E., \& Heffernan, P. (2006). New firm growth: Exploring processes and paths. Industry \& Innovation, 13(1), 1-20. doi:10.1080/13662710500513367.

Giuri, P., Ploner, M., Rullani, F., \& Torrisi, S. (2010). Skills, division of labor and performance in collective inventions: Evidence from open source software. International Journal of Industrial Organization, 28(1), 54-68. doi:10.1016/j.ijindorg.2009.07.004.

Granovetter, M. S. (1973). The strength of weak ties. The American Journal of Sociology, 78(6), 1360-1380.

Grant, R. M. (1996a). Towards a knowledge-based theory of the firm. Strategic Management Journal, 17(Special issue winter), 109-122.

Grant, R. M. (1996b). Prospering in dynamically-competitive environments: Organizational capability as knowledge integration. Organization Science, 7(4), 375-387.

Grimaldi, R., \& Grandi, A. (2005). Business incubators and new venture creation: An assessment of incubating models. Technovation, 25(2), 111-121. doi:10.1016/S0166-4972(03)00076-2.

Gulati, R., Nohria, N., \& Zaheer, A. (2000). Strategic networks. Strategic Management Journal, 21(3), 203-215. doi:10.1002/(SICI)1097-0266(200003)21:3<203:AID-SMJ102>3.0.CO;2-K.

Hackett, S. M., \& Dilts, D. M. (2004). A systematic review of business incubation research. The Journal of Technology Transfer, 29(1), 55-82. doi:10.1023/B:JOTT.0000011181.11952.0f.

Hansen, M. T., Chesbrough, H. W., Nohria, N., \& Sull, D. N. (2000). Networked incubators. Hothouses of the new economy. Harvard Business Review, 78(5), 74-84. (199).

He, Z.-L., \& Wong, P.-K. (2004). Exploration vs. exploitation: An empirical test of the ambidexterity hypothesis. Organization Science, 15(4), 481-494. doi:10.1287/orsc.1040.0078.

Heebels, B., \& Boschma, R. (2011). Performing in Dutch book publishing 1880-2008: The importance of entrepreneurial experience and the Amsterdam cluster. Journal of Economic Geography, 11(6), 1007-1029. doi:10.1093/jeg/lbq048.

Hoang, H., \& Antoncic, B. (2003). Network-based research in entrepreneurship; A critical review. Journal of Business Venturing, 18(2), 165-187. doi:10.1016/S0883-9026(02)00081-2.

Hu, T.-S., Chang, S.-L., Lin, C.-Y., \& Chien, H.-T. (2006). Evolution of knowledge intensive services in a high-tech region: The case of Hsinchu, Taiwan. European Planning Studies, 14(10), 1363-1385. doi: $10.1080 / 09654310600852530$.

Huber, G. P. (1991). Organizational learning: The contributing processes and the literatures. Organization Science, 2(1), 88-115.

Hughes, M., Hughes, P., \& Morgan, R. E. (2007a). Exploitative learning and entrepreneurial orientation alignment in emerging young firms: Implications for market and response performance. British Journal of Management, 18(4), 359-375. doi:10.1111/j.1467-8551.2007.00519.x.

Hughes, M., Ireland, R. D., \& Morgan, R. E. (2007b). Stimulating dynamic value: Social capital and business incubation as a pathway to competitive success. Long Range Planning, 40(2), 154-177. doi:10.1016/j.lrp.2007.03.008.

Johnson, B., Lorenz, E., \& Lundvall, B.-A. (2002). Why all this fuss about codified and tacit knowledge? Industrial and Corporate Change, 11(2), 245-262. doi:10.1093/icc/11.2.245.

Kautonen, T., Zolin, R., Kuckertz, A., \& Viljamaa, A. (2010). Ties that blind? How strong ties affect small business owner-managers' perceived trustworthiness of their advisors. Entrepreneurship \& Regional Development, 22(2), 189-209. doi:10.1080/08985620903168265.

Khan, M. S., Breitenecker, R. J., \& Schwarz, E. J. (2014). Entrepreneurial team locus of control: Diversity and trust. Management Decision, 52, 1057-1081. doi:10.1108/MD-06-2013-0349.

Kogut, B., \& Zander, U. (1992). Knowledge of the firm, combinative capabilities, and the replication of technology. Organization Science, 3(3), 383-397.

Lavie, D. (2006). The competitive advantage of interconnected firms: An extension of the resource-based view. Academy of Management Review, 31(3), 638-658.

Levitt, B., \& March, J. G. (1988). Organizational learning. Annual Review of Sociology, 14(1988), 319-340.

Li, Y.-R., \& Chen, Y. (2009). Opportunity, embeddedness, endogenous resources, and performance of technology ventures in Taiwan's incubation centers. Technovation, 29(1), 35-44. doi:10.1016/j. technovation.2008.06.002.

Lumpkin, G. T., \& Dess, G. G. (1996). Clarifying the entrepreneurial orientation construct and linking it to performance. Academy of Management Review, 21(1), 135-172.

March, J. G. (1991). Exploration and exploitation in organizational learning. Organization Science, 2(1), 71-87.

Mayring, P. (2000a). Qualitative Inhaltsanalyse. Grundlagen und Techniken (7th ed.). Weinheim: Deutscher Studien Verlag.

Mayring, P. (2000b). Qualitative content analysis. Forum Qualitative Sozialforschung, 1(2), 1-10. 
McAdam, M., \& Marlow, S. (2007). Building futures or stealing secrets? Entrepreneurial cooperation and conflict within business incubators. International Small Business Journal, 25(4), 361-382. doi:10. $1177 / 0266242607078563$.

McAdam, M., \& McAdam, R. (2008). High tech start-ups in university science park incubators: The relationship between the start-up's lifecycle progression and use of the incubator's resources. Technovation, 28(5), 277-290. doi:10.1016/j.technovation.2007.07.012.

McAdam, R., McAdam, M., \& Brown, V. (2009). Proof of concept processes in UK university technology transfer: An absorptive capacity perspective. R\&D Management, 39(2), 192-210.

Mian, S. A. (1996). Assessing value-added contributions of university technology business incubators to tenant firms. Research Policy, 25, 325-335.

Milius, P. B. (2008). Ten years in the system of entrepreneurship stimulation. Inzinerine EkonomikaEngineering Economics, 4, 42-45.

Mowery, D. C., Oxley, J. E., \& Silverman, B. S. (1996). Strategic alliances and interfirm knowledge transfer. Strategic Management Journal, 17, 77-91.

Murphy, G. B., Trailer, J. W., \& Hill, R. C. (1996). Measuring performance in entrepreneurship. Journal of Business Research, 2963(95), 15-23.

Nahapiet, J., \& Ghoshal, S. (1998). Social capital, intellectual capital and organizational advantages. Academy of Management Review, 23(2), 242-266.

NBIA. (2009). What is business incubation? https://www.inbia.org/resources/business-incubation-faq. Accessed 23 Apr 2014.

NBIA. (2014). Resource library. National Business Incubation Association. Retrieved from www.nbia.org.

Newbert, S. L. (2007). Empirical research on the resource-based view of the firm: An assessment and suggestions for future research. Strategic Management Journal, 28, 121-146. doi:10.1002/smj.

Nowak, M. J., \& Grantham, C. E. (2000). The virtual incubator: Managing human capital in the software industry. Research Policy, 29(2), 125-134. doi:10.1016/S0048-7333(99)00054-2.

O'Gorman, C., Byrne, O., \& Pandya, D. (2008). How scientists commercialise new knowledge via entrepreneurship. Journal of Technology Transfer, 33(1), 23-43. doi:10.1007/s10961-006-9010-2.

Oakey, R. (2007). Clustering and the R\&D management of high-technology small firms: In theory and practice. $R \& D$ Management, 37(3), 237-248.

Ozman, M. (2009). Inter-firm networks and innovation: A survey of literature. Economics of Innovation and New Technology, 18(1), 39-67. doi:10.1080/10438590701660095.

Patton, D. (2014). Realising potential: The impact of business incubation on the absorptive capacity of new technology-based firms. International Small Business Journal,. doi:10.1177/0266242613482134.

Patton, D., \& Marlow, S. (2011). University technology business incubators: Helping new entrepreneurial firms to learn to grow. Environment and Planning C: Government and Policy, 29(5), 911-926. doi:10. 1068/c10198b.

Patton, D., Warren, L., \& Bream, D. (2009). Elements that underpin high-tech business incubation processes. Journal of Technology Transfer, 34(6), 621-636. doi:10.1007/s10961-009-9105-7.

Peña, I. (2004). Business incubation centers and new firm growth in the Basque Country. Small Business Economics, 22, 223-236. doi:10.1023/B:SBEJ.0000022221.03667.82.

Penrose, E. T. (1959). The theory of the growth of the firm. New York: Wiley.

Phan, P. H., Siegel, D. S., \& Wright, M. (2005). Science parks and incubators: Observations, synthesis and future research. Journal of Business Venturing, 20(2), 165-182. doi:10.1016/j.jbusvent.2003.12.001.

Phelps, C., Heidl, R., \& Wadhwa, A. (2012). Knowledge, networks, and knowledge networks: A review and research agenda. Journal of Management, 38(4), 1115-1166. doi:10.1177/0149206311432640.

Portes, A. (1998). Social capital: Its origins and applications in modern sociology. Annual Review of Sociology, 24, 1-24.

Powell, W. W., Koput, K. W., \& Smith-Doerr, L. (1996). Interorganizational collaboration and the locus of innovation: Networks of learning in biotechnology. Administrative Science Quarterly, 41(1), 116. doi: $10.2307 / 2393988$.

Ratinho, T., Harms, R., \& Groen, A. (2013). Business incubators: (How) do they help their tenants? New Technology-Based Firms in the New Millennium, 10(10), 161-182. doi:10.1108/S18760228(2013)0000010011.

Rice, M. P. (2002). Co-production of business assistance in business incubators: An exploratory study. Journal of Business Venturing, 17(2), 163-187. doi:10.1016/S0883-9026(00)00055-0.

Richard, P. J., Devinney, T. M., Yip, G. S., \& Johnson, G. (2009). Measuring organizational performance: Towards methodological best practice. Journal of Management, . doi:10.1177/0149206308330560.

Rosenberg, N., \& Nelson, R. R. (1994). American universities and technical advance in industry. Research Policy, 23, 323-348. 
Rothaermel, F. T., \& Thursby, M. (2005a). Incubator firm failure or graduation? The role of university linkages. Research Policy, 34(7), 1076-1090. doi:10.1016/j.respol.2005.05.012.

Rothaermel, F., \& Thursby, M. (2005b). University-incubator firm knowledge flows: Assessing their impact on incubator firm performance. Research Policy, 34, 305-320. doi:10.1016/j.respol.2004.11.006.

Rothschild, L., \& Darr, A. (2005). Technological incubators and the social construction of innovation networks: An Israeli case study. Technovation, 25(1), 59-67. doi:10.1016/S0166-4972(03)00064-6.

Ruef, M., Aldrich, H. E., \& Carter, N. M. (2003). The structure of founding teams: Homophily, strong ties, and isolation among U.S. entrepreneurs. American Sociological Review, 68(2), 195. doi:10.2307/1519766.

Sá, C., \& Lee, H. (2012). Science, business, and innovation: Understanding networks in technology-based incubators. $R \& D$ Management, 42(3), 243-253.

Salvador, E. (2011). Are science parks and incubators good 'brand names' for spin-offs? The case study of Turin. Journal of Technology Transfer, 36(2), 203-232. doi:10.1007/s10961-010-9152-0.

Schwartz, M. (2013). A control group study of incubators' impact to promote firm survival. The Journal of Technology Transfer, 38(3), 302-331. doi:10.1007/s10961-012-9254-y.

Schwartz, M., \& Hornych, C. (2008). Specialization as strategy for business incubators: An assessment of the Central German Multimedia Center. Technovation, 28(7), 436-449. doi:10.1016/j.technovation. 2008.02.003.

Schwartz, M., \& Hornych, C. (2010). Cooperation patterns of incubator firms and the impact of incubator specialization: Empirical evidence from Germany. Technovation, 30(9-10), 485-495. doi:10.1016/j. technovation.2010.05.001.

Scillitoe, J. L., \& Chakrabarti, A. K. (2010). The role of incubator interactions in assisting new ventures. Technovation, 30(3), 155-167. doi:10.1016/j.technovation.2009.12.002.

Shane, S. (2000). Prior knowledge and the discovery of entrepreneurial opportunities. Organization Science, 11(4), 448-469.

Shapiro, G., \& Markoff, J. (1998). Revolutionary demands: A content analysis of the Cahiers de Doléances of 1789. Stanford, CA: Stanford University Press.

Sharif, M. N. (2012). Technological innovation governance for winning the future. Technological Forecasting and Social Change, 79(3), 595-604. doi:10.1016/j.techfore.2011.12.004.

Sherman, H., \& Chappell, D. S. (1998). Methodological challenges in evaluating business incubator outcomes. Economic Development Quarterly, 12(4), 313-321. doi:10.1177/089124249801200403.

Sirmon, D. G., Hitt, M. A., Ireland, R. D., \& Gilbert, B. A. (2010). Resource orchestration to create competitive advantage: Breadth, depth, and life cycle effects. Journal of Management, 37(5), 1390-1412. doi:10.1177/0149206310385695.

Slotte-Kock, S., \& Coviello, N. (2010). Entrepreneurship research on network processes: A review and ways forward. Entrepreneurship Theory and Practice, 34(1), 31-57. doi:10.1111/j.1540-6520.2009.00311.x.

Soetanto, D. P., \& Jack, S. L. (2013). Business incubators and the networks of technology-based firms. Journal of Technology Transfer, 38(4), 432-453. doi:10.1007/s10961-011-9237-4.

Soetanto, D. P., \& van Geenhuizen, M. (2009). Social networks and competitive growth of university spin-off firms: A tale of two contrasting cities. Tijdschrift voor Economische en Sociale Geografie, 100(2), 198-209.

Soetanto, D. P., \& van Geenhuizen, M. (2010). Social capital through networks: The case of university spinoff firms in different stages. Tijdschrift voor Economische en Sociale Geografie, 101(5), 509-520. doi:10.1111/j.1467-9663.2010.00632.x.

Sofouli, E., \& Vonortas, N. S. (2007). S\&T parks and business incubators in middle-sized countries: The case of Greece. Journal of Technology Transfer, 32(5), 525-544. doi:10.1007/s10961-005-6031-1.

Somsuk, N., \& Laosirihongthong, T. (2014). A fuzzy AHP to prioritize enabling factors for strategic management of university business incubators: Resource-based view. Technological Forecasting and Social Change, 85, 198-210. doi:10.1016/j.techfore.2013.08.007.

Stam, W., Arzlanian, S., \& Elfring, T. (2014). Social capital of entrepreneurs and small firm performance: A meta-analysis of contextual and methodological moderators. Journal of Business Venturing, 29(1), 152-173. doi:10.1016/j.jbusvent.2013.01.002.

Stam, W., \& Elfring, T. (2008). Entrepreneurial orientation and new venture performance: The moderating role of intra- and extraindustry social capital. Academy of Management Journal, 51(1), 97-111.

Sullivan, D. M., \& Marvel, M. R. (2011). Knowledge acquisition, network reliance, and early-stage technology venture outcomes. Journal of Management Studies, 48(6), 1169-1193. doi:10.1111/j.14676486.2010.00998.x.

Sung, T. K. (2007). Incubators and business ventures in Korea: Implications for manpower policy. International Journal of Technology Management, 38(3), 248-267.

Sung, T. K., Gibson, D. V., \& Kang, B. S. (2003). Characteristics of technology transfer in business ventures: The case of Daejeon, Korea. Technological Forecasting and Social Change, 70, 449-466. doi:10.1016/S0040-1625(02)00360-8. 
Teece, D., Pisano, G., \& Shuen, A. (1997). Dynamic capabilities and strategic management. Strategic Management Journal, 18(7), 509-533.

Theodorakopoulos, N., Kakabadse, N., \& McGowan, C. (2014). What matters in business incubation? A literature review and a suggestion for situated theorising. Journal of Small Business and Enterprise Development, 21(4), 1-30.

Thomson Reuters Social Science Citation Index. (2012). http://ip-science.thomsonreuters.com/mj1/scope/ scope_ssci/. Accessed 1 June 2016.

Tötterman, H., \& Sten, J. (2005). Start-ups: Business incubation and social capital. International Small Business Journal, 23(5), 487-511. doi:10.1177/0266242605055909.

Tsai, W. (2002). Social structure of 'coopetition' within a multiunit organization: Coordination, competition, and intraorganizational knowledge sharing. Organization Science, 13(2), 179-190.

Tsai, F.-S., Hsieh, L. H. Y., Fang, S.-C., \& Lin, J. L. (2009). The co-evolution of business incubation and national innovation systems in Taiwan. Technological Forecasting and Social Change, 76(5), 629-643. doi:10.1016/j.techfore.2008.08.009.

Uzzi, B. (1997). Social structures and competition in interfirm networks: The paradox of embeddedness. Administrative Science Quarterly, 42(1), 35-67.

Van Geenhuizen, M., \& Soetanto, D. P. (2009). Academic spin-offs at different ages: A case study in search of key obstacles to growth. Technovation, 29(10), 671-681. doi:10.1016/j.technovation.2009.05.009.

Van Rijnsoever, F. J., Van der Berg, J., Koch, J., \& Hekkert, M. P. (2015). Smart innovation policy: How network position and project composition affect the diversity of an emerging technology. Research Policy, 44(5), 1094-1107.

van Rijnsoever, F. J., Welle, L., \& Bakker, S. (2014). Credibility and legitimacy in policy-driven innovation networks: Resource dependencies and expectations in Dutch electric vehicle subsidies. The Journal of Technology Transfer, 39(4), 635-661. doi:10.1007/s10961-013-9326-7.

Vick, T. E., Nagano, M. S., Santos, A., \& Cesar, F. (2013). Identifying the information management process and knowledge creation in technology-based companies: A Brazilian comparative case study. Knowledge Management Research \& Practice, 11(3), 278-287. doi:10.1057/kmrp.2012.8.

Vohora, A., Wright, M., \& Lockett, A. (2004). Critical junctures in the development of university high-tech spinout companies. Research Policy, 33(1), 147-175. doi:10.1016/S0048-7333(03)00107-0.

Walker, G., Kogut, B., \& Shah, W. (1997). Social capital, structural holes and the formation of an industry network. Organization Science, 8(2), 109-125.

Walter, A., Auer, M., \& Ritter, T. (2006). The impact of network capabilities and entrepreneurial orientation on university spin-off performance. Journal of Business Venturing, 21(4), 541-567. doi:10.1016/j. jbusvent.2005.02.005.

Wang, C. L., \& Ahmed, P. K. (2007). Dynamic capabilities: A review and research agenda. International Journal of Management Reviews, 9(1), 31-51. doi:10.1111/j.1468-2370.2007.00201.x.

Wang, C. L., \& Chugh, H. (2014). Entrepreneurial learning: Past research and future challenges. International Journal of Management Reviews, 16(1), 24-61. doi:10.1111/ijmr.12007.

Warren, L., Patton, D., \& Bream, D. (2009). Knowledge acquisition processes during the incubation of new high technology firms. International Entrepreneurship and Management Journal, 5(4), 481-495. doi:10.1007/s11365-009-0121-8.

Wasserman, S., \& Faust, K. (1994). Social network analysis methods and applications. Cambridge: Cambridge University Press.

Welter, F. (2011). Contextualizing entrepreneurship: Conceptual challenges and ways forward. Entrepreneurship: Theory and Practice, 35(1), 165-184. doi:10.1111/j.1540-6520.2010.00427.x.

Wernerfelt, B. (1984). A resource-based view of the firm. Strategic Management Journal, 5(2), 171-180.

Wiklund, J., \& Shepherd, D. (2003). Knowledge-based resources, entrepreneurial orientation, and the performance of small and medium-sized businesses. Strategic Management Journal, 24(13), 1307-1314. doi:10.1002/smj.360.

Witt, P. (2007). Entrepreneurs' networks and the success of start-ups. Entrepreneurship \& Regional Development: An International Journal, 16(5), 291-412. doi:10.1080/0898562042000188423.

Wright, M., Liu, X., Buck, T., \& Filatotchev, I. (2008). Returnee entrepreneurs, science park location choice and performance: An analysis of high-technology SMEs in China. Entrepreneurship: Theory and Practice, 32(January), 131-155. doi:10.1111/j.1540-6520.2007.00219.x.

Zahra, S. A., Wright, M., \& Abdelgawad, S. G. (2014). Contextualization and the advancement of entrepreneurship research. International Small Business Journal, 32(5), 479-500. doi:10.1177/0266242613519807.

Zolin, R., Kuckertz, A., \& Kautonen, T. (2011). Human resource flexibility and strong ties in entrepreneurial teams. Journal of Business Research, 64(10), 1097-1103. doi:10.1016/j.jbusres.2010.11.026. 